\title{
Site U1397
}

\author{
Expedition 340 Scientists $^{2}$
}

\section{Chapter contents}

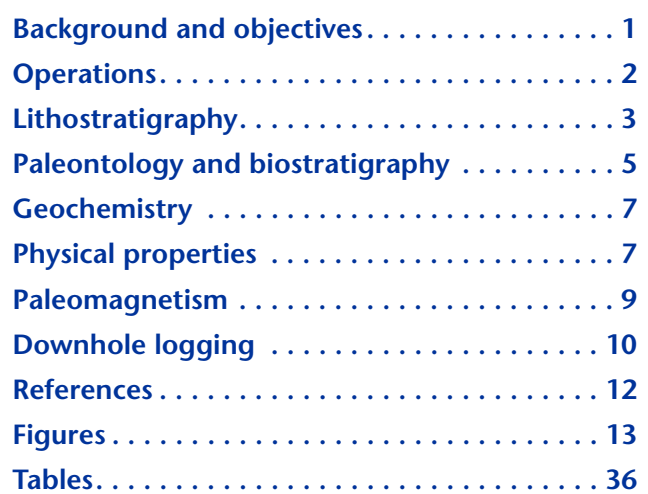

1Expedition 340 Scientists, 2013. Site U1397. In Le Friant, A., Ishizuka, O., Stroncik, N.A., and the Expedition 340 Scientists, Proc. IODP, 340: Tokyo (Integrated Ocean Drilling Program Management International, Inc.).

doi:10.2204/iodp.proc.340.107.2013

'Expedition 340 Scientists' addresses.

\section{Background and objectives}

Integrated Ocean Drilling Program (IODP) Site U1397 (proposed Site CARI-10B; $14^{\circ} 54.41^{\prime} \mathrm{N}, 61^{\circ} 25.35^{\prime} \mathrm{W} ; 2482$ meters below sea level [mbsl]) is located west of Martinique (Fig. F1). The bathymetric survey for Site U1397 revealed a region with a topographic high bound by large canyons. Site survey seismic data indicated that this site could, in the upper part, penetrate regular (unperturbed) sedimentary reflectors, whereas in the lower part some chaotic reflectors are visible. The drill site is located on the topographic high to try to avoid perturbations. Site U1397 is located very close to Core CAR-MAR 4 (7 m long) taken during the Caraval cruise in 2002. The CAR-MAR 4 core provides a sedimentary record that extends to $\sim 32 \mathrm{ka}$, as determined by $\delta^{18} \mathrm{O}$ chronostratigraphy. The sedimentation rate (including tephra) is $\sim 20 \mathrm{~cm} / \mathrm{k} . \mathrm{y}$. (Boudon et al., submitted). Correlating the tephra sampled in the core to onshore deposits of the Montagne Pelée Volcano shows that a significantly greater number of tephra layers are deposited in the marine environment than have been identified during onshore studies (e.g., 25 tephra layers were identified in the core between 5 and $15 \mathrm{ka}$, whereas only 10 magmatic events were previously recognized in onshore studies).

The objective for Site U1397 was to characterize the eruptive history of Martinique and the chaotic units appearing in the seismic profiles of this site. The cores retrieved will significantly improve our understanding of the eruptive history of Martinique in space and time, as we plan to sample material reaching back $>1$ m.y. (assuming a sedimentation rate of $20 \mathrm{~cm} / \mathrm{k} . \mathrm{y}$. and a total target depth of 314 meters below seafloor [mbsf]). We expect to identify and date layers related to the Montagne Pelée and Pitons du Carbet Volcanoes and to sample the region related to the transition of volcanism from the Pitons du Carbet and Mont Conil Volcanoes to the Montagne Pelée Volcano. The end of volcanic activity at the Pitons du Carbet and Mont Conil Volcanoes ( 0.3-0.5 Ma) precedes the beginning of the Montagne Pelée activity. We want to test the hypothesis that more mafic and denser magma was erupted for a period of several thousand years following edifice collapse until a new lava cone reached sufficient volume to erupt more evolved lavas (Pinel and Jaupart, 2000; Boudon et al., 2007). This site could also contain tephra from Dominica volcanoes, which will be distinguished on the basis of geochemistry and microtextural characteristics (Machault, 2008). Volcanism on Dominica has been dominated by andesitic to dacitic eruption products since the Pleistocene (Lindsay et al., 2005). 


\section{Operations}

\section{Transit to Site U1397}

After a $113.0 \mathrm{nmi}$ transit from Site U1396 in cruise mode, the vessel arrived at Site U1397. The vessel stabilized over Site U1397 at 1945 h on 18 March 2012. All times reported in this volume are given in ship local time, which was Universal Time Coordinated (UTC) - $4 \mathrm{~h}$. The position reference was a combination of GPS signals and a single acoustic beacon. The positioning beacon was deployed at $2010 \mathrm{~h}$ on 18 March. At the end of operations at Site U1397, the beacon was sent an acoustic command to release. The beacon was retrieved at $2200 \mathrm{~h}$ on 23 March.

\section{Site U1397}

Site U1397 consists of two holes (Table T1). The original plan called for two holes to be cored to $~ 314$ mbsf. The first hole was successfully cored and was terminated at a total depth of $265.5 \mathrm{mbsf}$. The second hole was cored to a depth of 253.5 mbsf. Logging plans originally included a vertical seismic profile (VSP) experiment, but this was canceled when the diameter of the hole proved too large to use the Versatile Seismic Imager (VSI). Sixty-six cores were recorded for the site. There were two drilled intervals. The advanced piston corer (APC) was deployed 35 times. The cored interval with the APC was 225.7 mbsf with a recovery of $226.17 \mathrm{~m}$ of core $(100.2 \%)$. The extended core barrel (XCB) was deployed 31 times. The cored interval with the XCB was $284.1 \mathrm{mbsf}$ with a recovery of only $49.49 \mathrm{~m}$ of core $(17 \%)$. Overall recovery for Site U1397 was 54\%. Hole U1395B was successfully logged with both the Formation MicroScanner (FMS)-sonic and triple combination (triple combo) logging strings. Total time spent at Site U1397 was $127.0 \mathrm{~h}$.

\section{Hole U1397A}

The vessel arrived at Site U1397 and was in position at $1950 \mathrm{~h}$ on 18 March 2012. After an uneventful pipe trip, the top drive was picked up and the bit was spaced out to spud Hole U1397A. The initial corrected precision depth recorder (PDR) reading was 2489.5 meters below rig floor (mbrf). The bit was initially set at $2484.5 \mathrm{mbrf}$, and the hole was spudded at $0422 \mathrm{~h}$ on 19 March. The seafloor depth was calculated from the length of the first core $(0.3 \mathrm{~m})$ to be 2493.7 mbrf $(2482.2 \mathrm{mbsl})$. Orientation was performed with the FlexIt tool on the first nine cores. Nonmagnetic core barrels were used for APC coring for Cores 340-U1397A-1H through 17H. Advanced piston corer temperature tool (APCT-3) measurements were taken on Cores $5 \mathrm{H}$ through $7 \mathrm{H}$. An APCT-3 measurement was attempted on Core $3 \mathrm{H}$, but the electronics failed and data could not be downloaded. The majority of the piston cores were incomplete strokes, and the hole was advanced by recovery. After reaching refusal with the APC, the $\mathrm{XCB}$ was deployed, and $\mathrm{XCB}$ coring continued to 265.5 mbsf. Coring was terminated after Core 35X, short of the 314 mbsf target depth, because of time constraints. Difficult hole conditions contributed to lengthening the coring time required to advance the hole. Nineteen piston cores were taken over a $117.3 \mathrm{~m}$ interval with a total recovery of $118.1 \mathrm{~m}$ of core. Fifteen XCB cores were taken over a $143.80 \mathrm{~m}$ interval. Only $26.10 \mathrm{~m}$ were recovered $(18 \%)$, and the hole was terminated at $265.5 \mathrm{mbsf}$. Overall core recovery for Hole U1397A was 55\%. After the completion of $\mathrm{XCB}$ coring, the drill string was pulled back with the top drive still installed, and the bit cleared the seafloor at $0055 \mathrm{~h}$ on $21 \mathrm{March}$, ending Hole U1397A. Total time spent in Hole U1397A was 53.25 h.

\section{Hole U1397B}

After clearing the seafloor from Hole U1397A, the vessel was offset $20 \mathrm{~m}$ east and Hole U1397B was spudded at $0252 \mathrm{~h}$ on $21 \mathrm{March} 2012$. The seafloor depth was calculated from the length of the first core to be 2492.9 mbrf ( $2481.4 \mathrm{mbsl})$. Nonmagnetic core barrels were used for all cores. APCT-3 measurements were taken on Cores $340-\mathrm{U} 1397 \mathrm{~B}-3 \mathrm{H}, 4 \mathrm{H}$, and $7 \mathrm{H}$. Similar to Hole U1397A, most of the piston cores were partial strokes and the hole was advanced by recovery. After reaching refusal with the APC on Core $17 \mathrm{H}$, the XCB was deployed, and XCB coring continued to 265.5 mbsf. Coring was terminated after Core $33 \mathrm{X}$ short of the $314 \mathrm{mbsf}$ target depth because of time constraints. Difficult hole conditions lengthened the coring time required to advance the hole. Seventeen piston cores were taken over a $108.4 \mathrm{~m}$ interval with a total recovery of $108.07 \mathrm{~m}$ of core. Sixteen XCB cores were taken over a $140.30 \mathrm{~m}$ interval. Only $23.39 \mathrm{~m}$ were recovered $(17 \%)$, and the hole was terminated at $253.5 \mathrm{mbsf}$. Overall core recovery for Hole U1397B was 53\%. At the conclusion of coring, Hole U1397B was conditioned with a $30 \mathrm{bbl}$ high-viscosity mud sweep. Hole conditions at the end of coring were very bad, and the top drive had to be left in to pull back. Both rotation and circulation were required while the drill string was pulled back to 220 mbsf. The hole was not displaced with logging mud because the mud would have simply pumped away during the necessary circulation. The drill string was then pulled back to 2645 mbrf, the top drive was set back, knobbies were added to the drill string, the bit was set at $81.6 \mathrm{mbsf}$, and the pipe was hung from the blocks. The Schlumberger wireline was then rigged up for logging and the triple combo was deployed. Because of hole conditions, we 
decided to not include the two nuclear sources in the triple combo tool string. Two successful passes were made to a depth of 221.1 mbsf. The tool string was then pulled back to surface and rigged down. The FMS-sonic tool string was then picked up. The tool was run to 210.3 mbsf and two passes were made over the length of the open hole. The second pass was only able to reach $\sim 205$ mbsf because of bridging or infilling in the hole. The tools were then recovered to the surface and rigged down. At the beginning of the last logging run, the driller noted overpull on the drill string of $70 \mathrm{klbs}$. After the FMS-sonic was laid out, the top drive was picked up and, using rotation and overpull, the drill string was worked free from the formation. The knobbies were then laid out, the top drive was set back, and the drill string was pulled from the hole. The bit cleared the rotary table at $0240 \mathrm{~h}$, and the drill floor was secured at $0245 \mathrm{~h}$ on 24 March, ending Site U1397 and Hole U1397B. The vessel then proceeded underway to Site U1398. Total time spent on Hole U1397B was $73.75 \mathrm{~h}$.

\section{Lithostratigraphy}

Two holes were drilled at Site U1397: Hole U1397A was drilled to $265 \mathrm{mbsf}$, and Hole U1397B was drilled to 255 mbsf. In both holes a good stratigraphy can be established to 120 mbsf. Below this depth, large parts of the section were not recovered, and it was not possible to establish a detailed stratigraphy.

Sediment recovered at Site U1397 was divided into eight lithostratigraphic units (A-H). Each unit consists of various combinations of hemipelagic muds, volcaniclastic or mixed (volcaniclastic-bioclastic) turbidites, and tephra fallout. Each lithology is described in detail "Lithostratigraphy" in the "Site U1394" chapter (Expedition 340 Scientists, 2013b). Good correlations can be established between the two holes, and the depths of the correlated units are similar. We observed a larger proportion of turbidites and a smaller proportion of tephra in some of the units in Hole U1397B than were observed in Hole U1397A. It is likely that most of the missing tephras were eroded during the emplacement of the turbidites.

As with previous sites, boundaries for each of the lithostratigraphic units are defined by abrupt or gradational changes in the abundance of lithologies, distinctive marker horizons, or different mineralogical compositions of tephra and unusually thick turbidites.

\section{Unit A}

Depths: Hole U1397A = 0-28 mbsf, Hole U1397B = 0-26 mbsf
Unit A extends from 0 to 28 mbsf in Hole U1397A and from 0 to 26 mbsf in Hole U1397B. The top of Unit A is marked by a $13 \mathrm{~cm}$ thick, oxidized brown hemipelagic mud that contains very fine sand layers and has high water content. Below this, the main part of Unit A is composed of a thick sequence of gray, muddy hemipelagic sediment with abundant interbedded volcaniclastic sand layers. Most of these sand layers, massive or normally graded and always sorted, are interpreted as tephra fallout deposits; only three thicker unsorted layers are recognized as turbidites.

The number of visually identified tephra layers is 200. There are probably more tephra layers, as some of the layers, which are $\leq 50 \mathrm{~cm}$ thick, are the result of successive eruptions. These successive eruptions form stacked tephra layers that are not separated by hemipelagic mud. We observed good correlation between Holes U1397A and U1397B, and the base of Unit $A$ is at 28 and 26 mbsf, respectively. The only significant difference in Unit A between the two holes is the presence of slightly thicker turbidite sequences in Hole U1397B. Based on the mineralogical composition of the tephra (presence or absence of amphiboles), we can identify their origin. Most of the tephras are from Montagne Pelée (Martinique), whereas the others are from the volcanoes of Dominica. Dominica is located north of Site U1397. The stratigraphy recognized in the uppermost part of Unit A is identical to the stratigraphy established on the basis of previous studies done on a $7 \mathrm{~m}$ long piston core (Boudon et al., submitted).

\section{Unit B}

Depths: Hole U1397A = 28-53 mbsf, Hole U1397B = 26-53 mbsf

Unit B extends from 28 to 53 mbsf in Hole U1397A and from 26 to 53 mbsf in Hole U1397B and is composed of a thick sequence of interbedded hemipelagic mud, tephra, and volcaniclastic turbidites. The proportion of turbidites is higher than that found in Unit A. Most of the turbidites are 1-3 $\mathrm{m}$ thick, are normally graded, and contain white, nonaltered pumices in proportions from a few percent to $>40 \%$. The turbidite matrix is composed of a high proportion of crystals, a very low proportion of carbonates, and lava clasts (massive to poorly vesiculated). The low proportion of carbonate in these turbidites indicates that they are associated with explosive volcanic events, either by direct emplacement of pyroclastic flows or by remobilization of pyroclastic flow deposits. Most of the tephra layers are dark and fine-grained and are frequently normally graded. They resemble the tephra layers in Unit A, except for two or three thick layers that are several tens of centimeters thick 
and contain abundant pumice granules. These thick and coarse tephra originate from large plinian eruptions of the neighboring islands.

\section{Unit C}

Depths: Hole U1397A = 53-77 mbsf, Hole U1397B = 53-78 mbsf

Unit C extends from 53 to 77 mbsf in Hole U1397A and from 53 to 78 mbsf in Hole U1397B and is separated into two subunits (C-1 and C-2).

\section{Subunit C-1}

Subunit C-1 (53- 74 mbsf in Hole U1397A and 5372 mbsf in Hole U1397B) is dominantly composed of thick mixed (bioclastic-volcaniclastic) turbidites. The proportion of biogenic and detrital carbonate grains can vary from $40 \%$ to $80 \%$. Volcanic components are dominated by crystals, massive lava, and, in some cases, pumice in low proportions. One of the turbidites is $5 \mathrm{~m}$ thick and massive, but it shows an evolution from the base to the top from dark gray to light gray corresponding to a decreasing proportion of volcanic material. At the base of Subunit C-1, two volcaniclastic turbidites are recognized, one rich in pumice. The proportion of hemipelagic mud is very low between turbidites, and intervening hemipelagic mud is frequently absent.

\section{Subunit C-2}

Subunit C-2 (74-77 mbsf in Hole U1397A and 7278 mbsf in Hole U1397B) comprises a debris flow deposit and a section of deformed sediment $(340 \mathrm{~cm}$ and $520 \mathrm{~cm}$ thick, respectively, in Holes U1397A and U1397B). The deformed sediment contains abundant, highly contorted mud and lava clasts. The debris flow deposit contains very abundant deformed mud clasts. This debris flow facies comprises the main part of this subunit in Hole U1397A $(320 \mathrm{~cm})$ and is $160 \mathrm{~cm}$ thick in Hole U1397B. Subunit C-2 can be interpreted as a slump of submarine material, including sediment and a debris flow.

\section{Unit D}

Depths: Hole U1397A = 77-91 mbsf, Hole U1397B = 78-95 mbsf

Unit D extends from 77 to 91 mbsf in Hole U1397A and from 78 to 95 mbsf in Hole U1397B and is composed of a series of volcaniclastic turbidites and few tephra layers interbedded with hemipelagic mud. Tephra layers are better represented in Hole U1397A than in Hole U1397B. These layers are located both at the top and base of the unit where two successions of $\sim 20$ tephra layers are observed. Turbidites are the dominant component of Hole U1397B. Hemipelagic sediment is in very low proportion, attesting to the important erosional character of the successive turbidites. In Hole U1397A, a $1 \mathrm{~m}$ thick zone of deformed sediment is present. This zone is not observed in Hole U1397B.

\section{Unit E}

Depths: Hole U1397A $=91-150$ mbsf, Hole $\mathrm{U} 1397 \mathrm{~B}=95-150 \mathrm{mbsf}$

Unit E extends from 91 to 150 mbsf in Hole U1397A and from 95 to 150 mbsf in Hole U1397B and is composed of a series of thick massive to normally graded volcaniclastic turbidites. These turbidites contain a large proportion of massive to poorly vesiculated lava. They represent $95 \%$ of the unit, with hemipelagic mud only representing 5\%. No tephra layers are observed. Unit E is observed in Holes U1397A and U1397B approximately at the same depth. The base of Unit $\mathrm{E}$ is not observed. Below the depth of $122 \mathrm{mbsf}$ in Hole U1397A and 115 mbsf in Hole U1397B, the stratigraphy is more uncertain because core recovery was very low $(<10 \%)$. No sediment was recovered between 122 and 150 mbsf in Hole U1397A or between 115 and 150 mbsf in Hole U1397B.

\section{Unit F}

Depths: Hole U1397A $=150-168$ mbsf, Hole $\mathrm{U} 1397 \mathrm{~B}=150-160 \mathrm{mbsf}$

Unit $\mathrm{F}$ is observed between 150 and $168 \mathrm{mbsf}$ in Hole U1397A and between 150 and 160 mbsf in Hole U1397B. Unit F can be divided into two subunits (F-1 and $\mathrm{F}-2$ ) on the basis of sediment compaction.

Subunit F-1 (150-163 mbsf) is composed of a package of hemipelagic muds with a few interbedded tephra layers. This subunit is thicker in Hole U1397A than in Hole U1397B. Subunit F-2 (163-168 mbsf) is composed of the same sequence of sediment types as seen in Subunit F-1; sediment is weakly compacted at the top and progressively lithified into mudstones. Only two tephra layers are identified in Hole U1397A. Abundant bioturbation characterizes the mudstones.

\section{Unit G}

Depths: Hole U1397A $=168-230$ mbsf, Hole $\mathrm{U} 1397 \mathrm{~B}=160-247.5 \mathrm{mbsf}$ (bottom of the hole)

Unit $G$ extends from 168 to 230 mbsf in Hole U1397A and from 160 to 247.5 mbsf in Hole U1397B (bottom of the hole) and is composed of mud-rich sandstone layers and semiconsolidated, highly fractured, and contorted mudstones. This deformed unit comprises beds with different colors, which often exhibit strongly inclined contacts. Unit $G$ contains abundant lava clasts and few pebbles. In Hole U1397A, 
at 227 mbsf, a clast consists of green to violet clay, probably resulting from hydrothermal alteration on land. The presence of pebbles may also indicate an origin from the emerged island. Poor recovery from the two holes at this depth makes establishing a precise stratigraphy difficult; however, highly deformed sediment seems to be present, having a thickness of $\sim 60 \mathrm{~m}$. This deformed sediment is most likely indicative of mass movement derived from the subaerial or submarine parts of the neighboring islands.

At the base of Hole U1397B, at 229 mbsf, only a few clasts and a larger block were recovered. The block is composed of andesitic lava containing large phenocrysts of amphibole and quartz. Similar lava is generated by the Piton du Carbet Volcano, south of Montagne Pelée, and is unique in the area of Martinique and Dominica. The period of activity that generated this type of magma is dated $\sim 330-350 \mathrm{ka}$ on the basis of K-Ar dates obtained on the lava domes from the Piton du Carbet Volcano (Germa et al., 2011; Samper et al., 2008). This composition gives a maximum age for the base of the core.

\section{Unit H}

Depth: Hole U1397A = 230-259.6 mbsf (bottom of hole)

Unit $\mathrm{H}$ is only present in Hole U1397A and extends from 230 to 259.6 mbsf at the base of the hole. It is composed of heavily bioturbated hemipelagic mud. A few layers of bioclastic sandstone are interbedded within the mudstone. No volcanic layers are observed.

\section{Paleontology and biostratigraphy}

Core catcher samples at Site U1397 are largely composed of coarse-grained sediment containing low abundances of calcareous nannofossils and planktonic and benthic foraminifers at varying levels of preservation. For some sections, additional nannofossil sampling was carried out from the working half of the core, where fine-grained sediment was available. Where obtainable, biostratigraphic dates are generally nonsequential; however, throughout the site, a trend to older material with depth can be seen (see "Age models"). These factors, accompanied by the presence of poorly preserved shallow-water reef benthic foraminifers and coral fragments in many core catcher samples, suggest persistent reworking of the sediment. Biostratigraphic data derived from both calcareous nannofossils and planktonic foraminifers show that Site U1397 contains many levels of reworked sediment from the early Pleistocene and late Pliocene amid a background of late Pleistocene sedimentation (Fig. F2).

\section{Calcareous nannofossils}

Calcareous nannofossils from 21 core catcher samples from Hole U1397A were investigated, along with 18 from Hole U1397B. Generally, investigation of the core material found extreme mixing of late Miocene to early Pliocene sediment within a background of late Pleistocene sedimentation (Samples 340-U1397B24X-CC, 29X-CC, 31X-CC, and 32X-CC). Because of the coarse nature of the material retrieved in some core catcher samples in Hole U1397A, additional sampling from the working half of the core was carried out (Samples 340-U1397A-10H-2W, $96 \mathrm{~cm}$; 12H$1 \mathrm{~W}, 141 \mathrm{~cm}$; and 12H-3W, $120 \mathrm{~cm}$ ). In contrast, Hole U1397B core catcher samples were much more suitable for calcareous nannofossil analysis. Preservation of samples is generally good. Samples show a range of abundances, from abundant to common, with one sample completely barren.

Sample 340-U1397A-1H-CC is characterized by an upper Pleistocene species assemblage of Gephyrocapsa oceanica, Calcidiscus leptoporus, Helicosphaera hyalina, Ceratolithus cristatus, and small gephyrocapsid species, such as Gephyrocapsa sinuosa, Gephyrocapsa ericsonii, and Gephyrocapsa parallela. Small forms, such as Emiliania huxleyi, were more abundant than gephyrocapsid species. Thus, this sample was assigned to Zone CN15, with a maximum age of $0.085 \mathrm{Ma}$ (Thierstein et al., 1977; Okada and Bukry, 1980). Samples 340-U1397A-3H-CC to $10 \mathrm{H}-\mathrm{CC}$ were also assigned to Zone CN15; however, based on the relative decrease in E. huxleyi to gephyrocapsid species, these samples were assigned ages ranging from 0.085 to 0.25 Ma (Okada and Bukry, 1980; Kameo and Bralower, 2000).

Samples 340-U1397A-12H-CC to 35X-CC, including two additional non-core catcher samples (Samples 340-U1397A-12H-1W, $141 \mathrm{~cm}$, and 12H-3W, $120 \mathrm{~cm}$ ), contain common G. oceanica, Helicosphaera carteri var. wallichii, C. cristatus, C. leptoporus, and G. parallela. Specimens of $E$. huxleyi were hard to distinguish because of their small size, delicate construction, and moderate preservation. Because of the absence of Pseudoemiliania lacunosa, these samples were assigned to Zone CN14b. Scanning electron microscopy is needed to verify with certainty the presence or absence of E. huxleyi.

At the base of Hole U1397B (Samples 340-U1397B24X-CC, 29X-CC, 31X-CC, and 32X-CC), the effects of reworking are noticeable, suggesting a number of sediment emplacement episodes. Preservation of the reworked species is moderate to good, which may indicate a source close by. When analyzing these samples, care was taken in determining which species represent the true age of the background sediment. This sediment would have been assigned to Subzone 
CN13a because of the presence of Crenalithus doronicoides; however, because these specimens are clearly reworked, these dates are unlikely to represent background sedimentation and most likely represent the age of the transported material. Recovery in the remainder of Hole U1397B provided a very similar record to that of Hole U1397A, including abundance and preservation.

\section{Planktonic foraminifers}

Of the core catcher samples collected from Hole U1397A, 31 of 35 were analyzed for planktonic foraminiferal content, along with 29 of the 33 collected from Hole U1397B. The remaining cores retrieved no sediment. Planktonic foraminifers were present in most samples, although some were found at very low abundances, possibly because of the high volume of volcanic material (Samples 340-U1397A-20H-CC and $32 \mathrm{X}-1$ and $340-\mathrm{U} 1397 \mathrm{~B}-4 \mathrm{H}-\mathrm{CC}$ and $22 \mathrm{X}-\mathrm{CC})$. In samples with abundant specimens, the assemblage of planktonic foraminifers was diverse but dominated by Globigerinoides ruber (white and pink) and Globigerinoides sacculifer. Other abundant species include Globigerinoides elongatus, Globorotalia tumida, and Neogloboquadrina dutertrei (dextral). The fauna does not change significantly throughout Site U1397, and all species present are indicative of warm subtropical waters.

Datum species were not found in many of the samples; however, in both holes the datum species Globorotalia flexuosa (0.07-0.40 Ma) and Globigerinella calida (bottom occurrence at $0.22 \mathrm{Ma}$ ) were found in low numbers. The presence of these datum species at the top and base of both Holes U1397A and U1397B dates the sediment to younger than $0.4 \mathrm{Ma}$, within the Pleistocene. Other datum species were encountered toward the base of Hole U1397A (no equivalent datum species were found in Hole U1397B). Globorotalia tosaensis (top occurrence [T] at $0.61 \mathrm{Ma}$ ), Globorotalia limbata (T $2.39 \mathrm{Ma}$ ), and Globoturborotalia apertura (T $1.63 \mathrm{Ma}$ ) were found in Sections 340-U1397A-30X-1 and $32 \mathrm{X}-1$, which suggests the presence of much older transported material. Unfortunately, it is likely that postcruise sampling of the material recovered at this site would not yield better results because of the persistent reworked nature of the retrieved sediment. It should also be noted that this site is nearly past the resolution of foraminiferal biostratigraphy, as there are only two true datum species located within the roughly $240 \mathrm{~m}$ of sediment.

\section{Benthic foraminifers}

A total of 40 genera and 33 species were identified at Site U1397 in the $>150 \mu \mathrm{m}$ size fraction. Benthic foraminifers from Holes U1397A and U1397B varied in abundance, diversity, and preservation (moderate). Fourteen species are present in Hole U1397A and 26 in Hole U1397B. Rotaliids have low diversity and were present in low abundances (1-10 specimens per sample) overall in Holes U1397A and U1397B. Numerous samples (28) are dominated by Amphistegina (1-30 specimens per sample). This genus is common in reef environments ( $\leq 100 \mathrm{~m}$ depth), and their moderate to poor preservation is indicative of reworking associated with volcaniclastic sedimentation in the area. Buliminids are practically absent, except for Samples 340-U1397B-24X-CC, 25X-CC, and 29X-CC, which have low abundances (1-10 individuals per sample) overall. Similarly, miliolids are nearly absent in most samples with the exception of Quinqueloculina, which is dominant in Hole U1397A, and Pyrgo in Hole U1397B. Agglutinated foraminifers are extremely rare, with only two genera (Ammobaculites and Vulvulina) and one species (Vulvulina pennatula) present in one sample (340-U1397A-1H-CC). Benthic foraminiferal density is generally low at Site U1397, ranging between 1 and 63 foraminifers/g of sediment.

At Site U1397, Orthomorphina perversa, Pleurostomella alternans, Proxifrons inaequalis, Siphonodosaria cooperensis, Stilostomella pomuligera, and $V$. pennatula are present in relatively low abundances (1-10 specimens per sample) in most samples. $S$. cooperensis has a low abundance (1-10 specimens per sample) in Samples 340-U1397B-25X-CC and 27X-CC, whereas $S$. pomuligera has a moderate abundance (1-30 specimens per sample) in Sample 25X-CC. Based on the presence and persistence of the above group, a bathyal paleodepth is interpreted.

\section{Age models}

Three age models have been constructed from several biostratigraphic datums and the presence of a particular clast of volcanogenic origin that can be tied to the Piton du Carbet Volcano from 330 to 350 ka. Figures F3 and F4 represent the most likely estimates for ages from Holes U1397A and U1397B, respectively, using only robust biostratigraphic information. To construct these age models, any age relying on the top occurrence or absence of a fossil species has been removed, again because of the persistent and prolific reworking of sediment. This leaves only a few datums from which to construct a crude age model. This has been done using the planktonic foraminifers G. calida and G. flexuosa and the coccolithophorid E. huxleyi. The age models (biostratigraphic data only) for Holes U1397A and U1397B include the top of $G$. flexuosa $(0.07 \mathrm{Ma})$; however, it has been removed from consideration from the composite age model (see below). 
Figure F5 represents a composite age model, using biostratigraphic data from Holes U1397A and U1397B (red line) and the presence of volcanic clasts from Piton du Carbet within Hole U1397B (dark blue line, see "Lithostratigraphy" for further discussion). The resulting age model suggests an age younger than $220 \mathrm{ka}$ for the top $\sim 25 \mathrm{mbsf}$, younger than $250 \mathrm{ka}$ from $\sim 50$ to $\sim 100 \mathrm{mbsf}$, younger than $\sim 350 \mathrm{ka}$ from $100 \mathrm{~m}$ to nearly the base, and $400 \mathrm{ka}$ in the bottom core catcher sample. It should be noted that these ages are only a maximum age estimate and that a minimum age estimate is inappropriate given the prolific reworking of sediment.

\section{Geochemistry}

Samples for headspace analyses were taken from 18 depths throughout Hole U1397A. Samples from the upper 76 mbsf tend to have slightly higher methane concentrations (3.1-4.4 ppm) than those from 94 to 266 mbsf (2.3-3.7 ppm). No higher hydrocarbons were detected.

A total of 44 samples were taken for X-ray diffraction (XRD) and carbonate analysis. Most of the samples collected for XRD are dominantly volcanic and contain mainly plagioclase, hornblende, quartz, and amphibole. The hornblende appears to be more alkali rich than that observed in samples from around Montserrat (e.g., Section 340-U1397-7H-7; Fig. F6), and there appear to be other types of amphibole present (e.g., cummingtonite). Clay minerals are ubiquitous throughout the hole and more abundant than in samples from Montserrat. The dominant clay minerals are smectite, kaolinite, and glauconite. A fourth mineralogic type has been defined for a series of six samples taken at the base of Hole U1397A (Cores 340-U1397A-32X through 35X). Samples from these cores contain high abundances of clay minerals, with smectite being particularly abundant; dolomite is also present in significant quantity (e.g., Section 340-U1397A-32X-1), possibly reflecting the presence of hydrothermal alteration products.

Carbonates are generally calcite with minor aragonite, reflecting the greater depth of the site. $\mathrm{CaCO}_{3}$ concentrations are lower than they are in the sites around Montserrat, a difference which likely reflects the absence of any significant aragonite preservation; however, carbonate supply and/or greater dilution by noncarbonate sedimentation may also be involved (Fig. F7; Table T2).

Pore water alkalinity values increase with depth in the upper part of the core to reach a maximum of $\sim 5.1 \mathrm{mM}$ between 23 and $46 \mathrm{mbsf}$ before declining to $3.9 \mathrm{mM}$ in the deepest samples (164-182 mbsf), although one sample from 174 mbsf had an alkalinity of $5 \mathrm{mM}$ (Fig. F8A). pH values vary between 7.3 and 8.2 , but no consistent pattern is observable in the data. Ammonia concentrations are lower than those at comparable sites around Montserrat (Sites U1394 and U1395), which likely reflects the greater water depth at Site U1397 (Fig. F8B). The shape of the profile is similar to that of alkalinity, suggesting that both are dominated by diagenetic processes in the sediment column. Calcium concentrations decrease from the seawater value to $9.1 \mathrm{mM}$ at $23 \mathrm{mbsf}$ and then increase to $\sim 11 \mathrm{mM}$ in the deepest sample at 182 mbsf (Fig. F8C). Magnesium concentrations (which scatter around seawater value) (Fig. F8D) and potassium concentrations (which are higher in the upper $75 \mathrm{mbsf}$ and show a weak trend to lower values between 164 and 182 mbsf) (Fig. F8E) suggest that alteration of volcanic matter does not play a dominant role in defining the major element pore water concentrations. $\Sigma$ S concentrations decrease from near seawater value to $26.2 \mathrm{mM}$ at $52.5 \mathrm{mbsf}$ and then increase to near seawater concentration in the deepest samples (Fig. F8F), again suggesting that organic carbon-driven diagenesis is the major process in the upper part of the hole. Chloride concentrations are within the normal range (560-570 mM) expected for pore water obtained from squeezing carbonate-rich sediment and show a slight increase in the upper part of the hole (Table T3).

\section{Physical properties}

Variations in physical properties in Holes U1397A and U1397B are correlated to lithologic variations. In particular, high magnetic susceptibility is correlated with ash layers and volcaniclastic turbidites. High $P$-wave velocities and densities characterize sandy sediment and turbidites. Shear strength increases linearly with depth in the upper 30 mbsf but becomes more variable at greater depths. In the upper $61 \mathrm{~m}$, temperature increases linearly with depth with a temperature gradient of $70.0 \pm 8.8^{\circ} \mathrm{C} / \mathrm{km}$.

\section{Stratigraphic correlation between Holes U1397A and U1397B}

We used magnetic susceptibility and natural gamma radiation (NGR) to correlate depths between Holes U1397A and U1397B (Fig. F9). Hole U1397A is the reference hole for these correlations because it has the longest continuous record. Both holes have poor recovery at depths below 120 mbsf; it is therefore difficult to correlate below this depth. Correlation for the uppermost $25 \mathrm{~m}$ between the holes is good, with clearly matching peaks in magnetic susceptibility throughout this range; however, major discrepancies exist below 25 mbsf between the two holes. It was 
especially difficult to find clear correlations between 25 and 50 mbsf and all depths below 70 mbsf in the magnetic susceptibility data. As a result, we also looked at gamma ray attenuation (GRA) density and NGR to determine if better correlation points exist in these data sets. Ultimately, we used NGR data to tie points between 25 and 50 mbsf. We trimmed $10 \mathrm{~cm}$ off of each end of the core sections in the NGR data to ensure minimization of edge effects and found better correlation between 25 and 50 mbsf. We then cross-referenced our correlations using NGR with magnetic susceptibility as a quality control measure. In general, correlations are strongest in the uppermost $25 \mathrm{~m}$ and between 50 and 70 mbsf. At all other depths, correlation is poor. Our correlation coefficient is 0.24 using magnetic susceptibility data and 0.37 using NGR data. These values are artificially low because of meter-scale gaps and several core breaks between data sets (Analyseries software includes these zones to calculate correlation coefficient). We suggest that the poor correlation between 25 and $50 \mathrm{mbsf}$ results from real geologic differences between holes, consistent with observed differences between the cores. Geologic differences may also explain discrepancies below 80 mbsf. Where we make correlations, depth shifts for Hole U1397B never exceed $3 \mathrm{~m}$ and rarely exceed $1 \mathrm{~m}$. All picked correlation depth shifts are shown in Table $\mathbf{T} 4$.

\section{Gamma ray attenuation density, magnetic susceptibility, and $P$-wave velocity}

Magnetic susceptibility shows large variations $(300 \times$ $10^{-5}$ to $6880 \times 10^{-5} \mathrm{SI}$ ), with maximum values more than twice those measured at previously visited sites. High values of magnetic susceptibility correlate with the location of ash layers and volcaniclastic turbidites. GRA density $\left(1.8-2.4 \mathrm{~g} / \mathrm{cm}^{3}\right)$ increases slightly with increasing depth. NGR is approximately constant but is reduced at the depth interval (50-70 mbsf) where magnetic susceptibility is also uniformly low. $P$-wave velocity ranges between 1400 and $1750 \mathrm{~m} / \mathrm{s}$ with no significant downhole increase. Between 70 and $100 \mathrm{mbsf}$ and between 160 and $185 \mathrm{mbsf}, P$-wave velocity shows maximum values of up to $2200 \mathrm{~m} / \mathrm{s}$ related to basal parts of the turbidite units. Magnetic susceptibility typically increases with increasing depth within thick turbidite deposits (e.g., the turbidite unit at 52.5-55.0 mbsf in Hole U1397A). Also, bulk density marks turbidite units well but shows only a slight systematic increase with depth.

\section{Thermal conductivity}

Thermal conductivity was measured in 17 sections from Hole U1397A and 16 sections from Hole U1397B. Measured thermal conductivity is $1.037 \mathrm{~W} /(\mathrm{m} \cdot \mathrm{K})$ with a standard deviation of $0.127 \mathrm{~W} /(\mathrm{m} \cdot \mathrm{K})$ and a standard error on the mean of $0.022 \mathrm{~W} /(\mathrm{m} \cdot \mathrm{K})$.

\section{Shear strength}

Undrained shear strength $\left(S_{\mathrm{u}}\right)$ measurements made with the fall cone and automated vane shear (AVS) apparatus increase downhole $(1 \mathrm{kPa} / \mathrm{m})$ in the uppermost $\sim 30 \mathrm{~m}$ of Holes U1397A and U1397B. $S_{\mathrm{u}}$ measurements performed with the handheld penetrometer show large fluctuations in Hole U1397A $(>50 \mathrm{kPa})$, whereas in Hole U1397B, $S_{\mathrm{u}}$ values are consistent with those obtained with the fall cone and AVS $(<50 \mathrm{kPa})$. Between 30 and $55 \mathrm{mbsf}$, although measurements are variable and scattered in both holes, $S_{\mathrm{u}}$ increases with depth $(1 \mathrm{kPa} / \mathrm{m})$. From 55 to 65 mbsf no measurements could be made because of the coarse size of the sediment in Holes U1397A and U1397B (mainly sand). $S_{\mathrm{u}}$ measurements were successfully performed from 65 to $95 \mathrm{mbsf}$ in both holes, and values increase $(\leq 200 \mathrm{kPa}$ ) between 65 and $80 \mathrm{mbsf}$ and decrease from 80 to $95 \mathrm{mbsf}$. Available $S_{\mathrm{u}}$ measurements from 95 to 103 mbsf in Hole U1397A increase rapidly with depth (as high as $>100 \mathrm{kPa}$ ). From 95 to $150 \mathrm{mbsf}, S_{\mathrm{u}}$ measurements were not made because of the presence of coarse material. The last interval in which $S_{\mathrm{u}}$ measurements could be made, from 150 to $180 \mathrm{mbsf}$, has scattered values, from low $(<50 \mathrm{kPa})$ to very high $(>450 \mathrm{kPa})$. The scatter is consistent with the lithologic heterogeneity of the sediment type and may also reflect variable consolidation states.

\section{$P$-wave velocity}

Discrete measurements of $P$-wave velocity measured on the $x$-axis (PW-X) are consistent with the trend of $P$-wave logger (PWL) measurements. $P$-wave velocity increases slightly from 0 to $120 \mathrm{mbsf}$. Velocities near the seafloor average $\sim 1600 \mathrm{~m} / \mathrm{s}$ and are typical values for water-saturated sandy silt (Hamilton and Bachman, 1981).

\section{Moisture and density}

We collected 46 moisture and density (MAD) samples (40 from Hole U1397A and 6 from Hole U1397B; Fig. F10). Porosity ranges from $\sim 40 \%$ to $68 \%$, with two volcanic sand samples having a porosity of $<40 \%$. Porosity shows no trend with depth; however, in the upper $120 \mathrm{~m}$ porosity shows a larger range (40\%-68\%) compared to cores below this depth (60\%-68\%). Hemipelagic sediment has higher porosities than turbidites. Porosity of loose sands may be underestimated because of the draining of pore water during sampling or overestimated because of sediment reworking during core recovery. Alternatively, where 
core recovery, handling, or splitting processes reorganize sand grains, sandy sediment may become undercompacted and yield anomalously high porosities.

Bulk density ( $\rho$ ) for hemipelagic sediment ranges between 1.55 and $1.94 \mathrm{~g} / \mathrm{cm}^{3}$. Dark-colored volcaniclastic turbidites have systematically higher bulk densities $\left(1.75-2.40 \mathrm{~g} / \mathrm{cm}^{3}\right)$.

Grain density ranges between 2.48 and $3.17 \mathrm{~g} / \mathrm{cm}^{3}$. Hemipelagic sediment has grain densities between 2.6 and $2.85 \mathrm{~g} / \mathrm{cm}^{3}$ (with one outlier at $2.48 \mathrm{~g} / \mathrm{cm}^{3}$ ).

\section{Downhole temperature}

Temperature was measured with the APCT- 3 at the bottom of Cores 340-U1397A-5H, 6H, and 7H (36.5, 46.0 , and 55.5 mbsf, respectively) and Cores 340U1397B-3H, 4H, and 7H (25.6, 35.1, and $61.3 \mathrm{mbsf}$, respectively). Downhole temperature was monitored for $652,626,671,647,685$, and 647 s, respectively. Temperature was calculated from these time series of temperature measurements using TP-Fit (see APCT-3 user manual on the Cumulus/Techdoc database at iodp.tamu.edu/tasapps/). We assume a thermal conductivity $(k)$ of $1.0 \mathrm{~W} /(\mathrm{m} \cdot \mathrm{K})$ and $\rho \mathrm{C}=3.7 \times 10^{6} \mathrm{~J} / \mathrm{m}^{3} \mathrm{~K}$. To calculate uncertainty, we assume $k$ ranges from 0.9 to $1.1 \mathrm{~W} /(\mathrm{m} \cdot \mathrm{K})$ and $\rho \mathrm{C}$ is between $3.2 \times 10^{6}$ and $4.0 \times 10^{6} \mathrm{~J} / \mathrm{m}^{3} \mathrm{~K}$. At the base of Cores $340-\mathrm{U} 1397 \mathrm{~A}-5 \mathrm{H}$, $6 \mathrm{H}$, and $7 \mathrm{H}$ we obtained temperatures of $6.48^{\circ} \pm$ $0.06^{\circ} \mathrm{C}, 6.66^{\circ} \pm 0.03^{\circ} \mathrm{C}$, and $7.91^{\circ} \pm 0.02^{\circ} \mathrm{C}$, respectively. At the base of Cores 340-U1397B-3H, 4H, and $7 \mathrm{H}$ we obtained temperatures of $5.61^{\circ} \pm 0.05^{\circ} \mathrm{C}, 7.01^{\circ} \pm$ $0.03^{\circ} \mathrm{C}$, and $8.83^{\circ} \pm 0.04^{\circ} \mathrm{C}$, respectively. These reported uncertainties are greater than the error on the best-fit solution and the probe's measurement accuracy, and they are dominated by uncertainties in the thermal properties of the sediment. The temperature of ocean water at the seafloor was $4.26^{\circ} \mathrm{C}$.

A best-fit linear relationship between depth and our six temperature measurements gives a temperature gradient of $70.0^{\circ} \pm 8.8^{\circ} \mathrm{C} / \mathrm{km}$ (Fig. F11). Using measured thermal conductivity, the implied heat flow, if conductive, is $72 \pm 9 \mathrm{~mW} / \mathrm{m}^{2}$. The measured nearsurface heat flow at this site is lowered, relative to that at depth, by $4 \%$ owing to bathymetry and up $4 \%$ owing to sedimentation (Manga et al., 2012). There are no statistically significant deviations of measurements from a straight line that would be indicative of fluid flow (Manga et al., 2012).

\section{Paleomagnetism}

Cores 340-U1397A-1H through 17H and 340-U1397B$1 \mathrm{H}$ through $17 \mathrm{H}$ were recovered using nonmagnetic core barrels with the APC. All other APC cores were recovered using standard steel core barrels. The
FlexIt core orientation tool was used on all APC cores recovered with nonmagnetic barrels; thus, between 0 and 67 mbsf in Hole U1397A declination can be corrected to true north. Where FlexIt tool data were not available, declination was guided by the discrete inclination data (see "Paleomagnetism" in the "Methods" chapter [Expedition 340 Scientists, 2013a]). Expected inclination for the site is $28.0^{\circ}$ during normal polarity and $-28.0^{\circ}$ during reversed polarity, assuming a geocentric axial dipole (GAD). The archive halves of cores from Holes U1397A and U1397B were measured on the three-axis superconducting rock magnetometer (SRM) at $2.5 \mathrm{~cm}$ intervals (Table T5). Natural remanent magnetization (NRM) was measured before $\left(\mathrm{NRM}_{0}\right)$ and after stepwise alternating field demagnetization at $10 \mathrm{mT}\left(\mathrm{NRM}_{10}\right)$ and $20 \mathrm{mT}$ $\left(\mathrm{NRM}_{20}\right)$ for Cores 340-U1397A-1H through $4 \mathrm{H}$. Only $\mathrm{NRM}_{0}$ and $\mathrm{NRM}_{20}$ were measured on all other cores to maintain workflow through the laboratory. Twenty discrete samples were collected from the center of the working half of the core to compare to the SRM data (see "Paleomagnetism" in the "Methods" chapter [Expedition 340 Scientists, 2013a]).

Sediment recovered from Site U1397 was heterogeneous in composition and varied between layers of hemipelagic sediment and volcanic tephras and turbidites (see "Lithostratigraphy"). Using the detailed core description logs we only interpreted data measured on identifiable hemipelagic layers, as these appear the least disturbed and are more likely to provide information on the behavior of the geomagnetic field.

\section{Results}

$\mathrm{NRM}_{0}$ (red) and $\mathrm{NRM}_{20}$ (blue) intensities are shown for Holes U1397A and U1397B in Figures F12 and F13. $\mathrm{NRM}_{0}$ intensity is relatively high at $\sim 0.5-1 \mathrm{~m} / \mathrm{A}$. $\mathrm{NRM}_{20}$ is $\sim 10 \%$ of $\mathrm{NRM}_{0}$. This value reflects both the low coercivity of the sediment and the susceptibility of the material to drill string overprint. This overprint is typically removed by alternating field demagnetization at $20 \mathrm{mT}$ when using nonmagnetic barrels. Between 55 and $68 \mathrm{mbsf}$ in Hole U1397A and between 55 and 60 mbsf and 64 and $68 \mathrm{mbsf}$ in Hole U1397B, NRM intensity is very low. These low values are mirrored in the magnetic susceptibility profile (see "Physical properties"). This interval is a sandy mixed turbidite (see "Lithostratigraphy") and differs from the volcanic turbidites and tephras throughout the rest of the core. The lows in NRM and magnetic susceptibility therefore likely represent reduced concentrations of volcaniclastic derived ferrimagnetic minerals in this mixed deposit.

Hemipelagic sediment is discontinuous at Site U1397, particularly below $\sim 55$ mbsf. Above $\sim 55$ mbsf, SRM 
and discrete inclination in Holes U1397A and U1397B show scattered but positive inclination, clustering around the expected GAD inclination. Declination shows little variation, suggesting that all sediment and tephra $<55$ mbsf were deposited in the Brunhes Chron ( $<780 \mathrm{ka})$. Below this depth the record becomes increasingly discontinuous, making confident interpretation of the paleomagnetic data difficult. This interpretation is further hindered by evidence of rifling of declination within core sections recovered with the XCB. SRM inclination data in this interval are highly scattered over a range of around $-50^{\circ}$ to almost $90^{\circ}$ in both holes and are steeper than their corresponding discrete samples. Given the tendency of Expedition 340 cores to acquire a persistent magnetic overprint when not recovered using nonmagnetic core barrels, discrete inclination data may prove the only useful magnetostratigraphic tool below $\sim 121$ mbsf in Hole U1397A and 113 mbsf in Hole U1397B.

Excluding deposits with significant evidence of reworking, biostratigraphic ages suggest a maximum age of $400 \mathrm{ka}$ at the base of Hole U1397B ( 253 mbsf) (see "Paleontology and biostratigraphy"). Additional geological constraints include clasts of quartzrich andesite indicative of the eruption of Pitons du Carbet $(\sim 330-350 \mathrm{ka})$ at $\sim 250 \mathrm{mbsf}$ in Hole U1397B (see "Lithostratigraphy"). These diverse constraints suggests that all material recovered from Site U1397 was deposited in the Brunhes Chron. The majority of discrete inclination values from $\sim 55$ to $\sim 250 \mathrm{mbsf}$ show positive inclination; however, at a few depths, notably 152, 248, and 259 mbsf in Hole U1397A and 161 mbsf in Hole U1397B, negative inclinations were recorded both in SRM and discrete data. Without declination to confirm these data, coupled with the fracturing and contortion of this sediment (see "Lithostratigraphy"), it is likely that these data from lithified hemipelagic mudstones cannot be accurately interpreted to represent the behavior of the geomagnetic field during deposition. With this assumption, paleomagnetic data support the biostratigraphic and geological constraints for Hole U1397, at least to $\sim 240 \mathrm{mbsf}$, that all sediment was deposited within the current normal polarity chron. Using the GPTS of Cande and Kent (1995), this suggests sediment is younger than $780 \mathrm{ka}$.

\section{Downhole logging}

Acquisition of downhole logging measurements including gamma ray, acoustic velocity, magnetic susceptibility, and electrical resistivity and images were obtained on 23 March 2012 in Hole U1397B. Two tool strings (Fig. F14) were used to log a $\sim 140 \mathrm{~m} \mathrm{sec}-$ tion of the hole over $\mathrm{a} \sim 14 \mathrm{~h}$ period. The borehole was very enlarged, degrading in condition throughout the course of the logging program, including infilling of at least $16.5 \mathrm{~m}$.

\section{Operations}

Following the last core on deck, preparations for logging commenced, including circulating with weighted mud and pulling the pipe to $81.4 \mathrm{mbsf}$. Unlike previous logged holes during Expedition 340, Hole U1397B was not displaced with heavy mud because of the necessity to circulate while pulling pipe (see "Operations"). At 0515 h on 23 March 2012, pick up of the triple combo-Magnetic Susceptibility Sonde (MSS) tool string (see Fig. F11 in the "Methods" chapter [Expedition 340 Scientists, 2013a]) commenced. Because of hole conditions as reported by the drillers, the Hostile Environment Litho-Density Sonde (HLDS) was run without its ${ }^{137} \mathrm{Cs}$ source. It was also decided, on the basis of hole conditions, to $\log$ only to $\sim 220 \mathrm{mbsf}$, in order to keep the logging tools above the region with the most difficult drilling/coring conditions. The tool string tagged the bottom at 223 mbsf $(\sim 30 \mathrm{~m}$ shallower than total drilled depth), indicating that the hole had either filled in or bridged over at this depth. An initial uplog was then undertaken to 114 mbsf before the tool string was run back in the hole for a second and final uplog through the seafloor. On tagging the bottom of the hole, it was noted that $1 \mathrm{~m}$ of infill had occurred since the initial tag.

The original plan had been to conduct a VSP experiment using the VSI tool string as the second tool deployment at this hole. However, because of a very enlarged hole diameter (in excess of 20 inches over most of the logged interval), as reported by the caliper measurement from the triple combo, it was decided to cancel this tool string run. The VSI relies on good coupling with the borehole walls to anchor the sonde, which would not have been possible in this oversized borehole.

The FMS-sonic was the second tool string to be deployed in Hole U1397B, with tools being picked up at $1130 \mathrm{~h}$. The downlog indicated seafloor at $2481.5 \mathrm{mbsl}$, and the hole depth was found to be shallower than that indicated by the triple combo, at a depth of 212 mbsf. An initial uplog to 115 mbsf was undertaken before returning to the bottom of the hole (206.5 $\mathrm{mbsf}=5.5 \mathrm{~m}$ of infill over a $\sim 20 \mathrm{~min}$ period) for a final uplog through the seafloor. Tools were at the surface by $1800 \mathrm{~h}$, and the tools were laid out and the rig floor handed over to the drill crew by $1910 \mathrm{~h}$.

\section{Data processing and quality assessment}

Figures F15, F16, and F17 show a summary of the main logging data recorded in Hole U1397B. Following 
acquisition, the downhole measurements data were processed. The total gamma ray log from the main pass of the triple combo was used as the reference log and was shifted to seafloor; it is the log to which all other logs (from this tool string and the FMS-sonic tool string) were depth-matched.

The oversized hole diameter has implications for all downhole logging measurements recorded in Hole U1397B; therefore, logging data should be interpreted with caution. The calipers run during these logging operations (HLDS and FMS) were generally opened to their full extent, and, as such, actual hole size through much of the open hole interval is not known. The HLDS caliper maximum reach is 20 inches, so the hole must have been generally greater than this in diameter (see hole size track in Fig. F15). As shown in Figure F16, the FMS caliper arms were also open to their full extent ( 15 inches) over much of the logged interval. Hole diameter decreased between 92 and 124 mbsf between the triple combo and FMS-sonic tool string runs, indicating that the hole was gradually collapsing over the course of the $14 \mathrm{~h}$ logging period.

The condition and size of the borehole are principal factors in evaluating data quality. Because the tools could not be reliably positioned (centralized or eccentralized) within this enlarged borehole, data quality is likely compromised. Measurements such as gamma ray are clearly affected by the large borehole size, whereas deep reading measurements such as electrical resistivity and sonic velocity are less affected. Gamma ray measurements show some significant variability between passes of the same tool string (Fig. F18; 160-198 mbsf) and between the two tool string runs (Fig. F16; 106-160 mbsf). This suggests that the tool was in a different position relative to the borehole wall between passes and/or that the borehole condition was rapidly changing between tool runs. The degree of separation between the different electrical resistivity curves (R3, R5, RT) can be used as an indicator of the quality of the data. In this case, where the curves are greatly separated (e.g., Fig. F15; 200-210 mbsf) the measurements are likely dominated by the fluid resistivity as a consequence of the enlarged borehole. There are also intervals where the resistivity curves are closer together (Fig. F15; 160-170 mbsf), which indicates better quality data. Magnetic susceptibility data are also affected by enlarged borehole conditions; however, downhole trends and relative changes should be reliable. The high coherence indicated by the red areas in the compressional velocity $\left(V_{\mathrm{P}}\right)$ track in Figure F16 suggests that, despite the enlarged hole, the tool was able to capture the compressional wave arrivals over a significant portion of the logged interval. Both $V_{\mathrm{P}}$ and shear wave velocity $\left(V_{S}\right)$ will be reprocessed post- cruise in order to improve the velocity data set. Perhaps most significantly affected by the enlarged borehole conditions are the FMS images, which largely reflect the electrical properties of the borehole fluid rather than the formation. FMS pad contact with the borehole wall was rare (Fig. F19).

\section{Logging stratigraphy}

The $140 \mathrm{~m}$ open-hole section of Hole U1397B was divided into four logging units on the basis of characteristics identified across the different geophysical properties measured. The different properties of these units are summarized below.

\section{Logging Unit 1}

Logging Unit 1 (85-90 mbsf) is characterized by relatively consistent values of resistivity (average = $1.49 \Omega \mathrm{m})$ and gamma ray and an average value for $V_{\mathrm{P}}$ of $\sim 1650 \mathrm{~m} / \mathrm{s}$. This is coupled with a generally decreasing trend in magnetic susceptibility.

\section{Logging Unit 2}

In contrast to the overlying unit, logging Unit 2 (90127 mbsf) is characterized by four intervals on the scale of 5-10 $\mathrm{m}$ that each exhibit increasing resistivity and $V_{\mathrm{P}}$ downhole with sharp bases (Figs. F15, F16). The boundaries to these intervals correspond with distinct changes in the magnetic susceptibility $\log$. Although the general trend in magnetic susceptibility is decreasing downward, local highs do correspond with the elevated resistivity and $V_{\mathrm{P}}$ values at the base of the intervals. Overall values of resistivity and $V_{\mathrm{P}}$ are elevated with respect to logging Unit 1 (mean resistivity $=1.99 \Omega \mathrm{m}$; mean $V_{\mathrm{p}}=1740 \mathrm{~m} / \mathrm{s}$ ).

\section{Logging Unit 3}

Logging Unit 3 (127-185 mbsf) shows a return to less variable resistivity and $V_{\mathrm{p}}$ values. The unit has been divided into two subunits on the basis of a subtle change in the character of the logs, most distinctive in the magnetic susceptibility. The amplitude of variations in the magnetic susceptibility data are much greater in logging Subunit 3A (127-155 mbsf) than in logging Subunit 3B (155-185 mbsf), although the frequency of changes is very similar.

\section{Logging Subunit $3 A$}

Resistivity is relatively constant in logging Subunit $3 \mathrm{~A}$, with an average value of $1.48 \Omega \mathrm{m}$. Despite some moderately large excursions from the base value of magnetic susceptibility, there is no net change downhole. $V_{\mathrm{P}}$ shows low amplitude variability in Subunit 3A with somewhat higher values in the 
lower half of the subunit (Fig. F16). Overall $V_{\mathrm{p}}$ has an average value of $\sim 1710 \mathrm{~m} / \mathrm{s}$.

\section{Logging Subunit 3B}

In combination with the drop in magnetic susceptibility amplitude, there is an increase in amplitude of the $V_{\mathrm{p}} \log$ in logging Subunit 3B (mean $=\sim 1760 \mathrm{~m} / \mathrm{s}$ ). The $V_{\mathrm{p}}$ peaks do not relate to the changes in the other logs in a consistent way. Instead, $V_{\mathrm{p}}$ highs in the top half of the subunit correspond to lows in magnetic susceptibility and resistivity, whereas in the lower half of the subunit the highs correspond to peaks in resistivity and magnetic susceptibility (Figs. F15, F16). The division of the subunit also marks a reduced separation between the true (RT) and deepest (R5) resistivity curves. True resistivity is relatively consistent downhole with a mean value of $1.49 \Omega \mathrm{m}$.

\section{Logging Unit 4}

Logging Unit 4, which extends from 185 mbsf to the base of the hole, is marked by elevated values in resistivity (mean $=2.52 \Omega \mathrm{m}$ ) and magnetic susceptibility relative to the overlying unit. There appears to be an interval of high resistivity and $V_{\mathrm{p}}$ between 185 and 190 mbsf. However, this measurement could be an artifact of degrading conditions at the base of the logged interval. Below this unit, resistivity increases toward the base of the unit with the curves becoming increasingly separated. Magnetic susceptibility, the measurement that extends to the greatest depth in the borehole, has a relatively consistent profile throughout the unit. $V_{\mathrm{P}}$ in this logging unit is elevated (average $=\sim 1900 \mathrm{~m} / \mathrm{s}$ ) with respect to the overlying units and completes a downhole trend of increasing $V_{\mathrm{p}}$.

\section{References}

Boudon, G., Le Friant, A., Komorowski, J.-C., Deplus, C., and Semet, M.P., 2007. Volcano flank instability in the Lesser Antilles arc: diversity of scale, processes, and temporal recurrence. J. Geophys. Res., [Solid Earth], 112:B08205. doi:10.1029/2006JB004674

Boudon, G., Villemant, B., Le Friant, A., Paterne, N., and Cortip, E., submitted. Role of large flank collapse events on magma exsolution of volcanoes: insights from the Lesser Antilles arc. J. Volcanol. Geotherm. Res.

Cande, S.C., and Kent, D.V., 1995. Revised calibration of the geomagnetic polarity timescale for the Late Cretaceous and Cenozoic. J. Geophys. Res., [Solid Earth], 100(B4):6093-6095. doi:10.1029/94JB03098

Expedition 340 Scientists, 2013a. Methods. In Le Friant, A., Ishizuka, O., Stroncik, N.A., and the Expedition 340 Scientists, Proc. IODP, 340: Tokyo (Integrated Ocean Drilling Program Management International, Inc.). doi:10.2204/iodp.proc.340.102.2013
Expedition 340 Scientists, 2013b. Site U1394. In Le Friant, A., Ishizuka, O., Stroncik, N.A., and the Expedition 340 Scientists, Proc. IODP, 340: Tokyo (Integrated Ocean Drilling Program Management International, Inc.). doi:10.2204/iodp.proc.340.104.2013

Germa, A., Quidelleur, X., Lahitte, P., Labanieh, S., and Chauvel, C., 2011. The K-Ar Cassignol-Gillot technique applied to western Martinique lavas: a record of Lesser Antilles arc activity from 2 Ma to Mount Pelée volcanism. Quat. Geochronol., 6(3-4):341-355. doi:10.1016/ j.quageo.2011.02.001

Hamilton, E.L., and Bachman, R.T., 1982. Sound velocity and related properties of marine sediments. J. Acoust. Soc. Am., 72(6):1891-1904. doi:10.1121/1.388539

Kameo, K., and Bralower, T.J., 2000. Neogene calcareous nannofossil biostratigraphy of Sites 998, 999, and 1000, Caribbean Sea. In Leckie, R.M., Sigurdsson, H., Acton, G.D., and Draper, G. (Eds.), Proc. ODP, Sci. Results, 165: College Station, TX (Ocean Drilling Program), 3-17. doi:10.2973/odp.proc.sr.165.012.2000

Lindsay, J.M., Trumbull, R.B., and Siebel, W., 2005. Geochemistry and petrogenesis of late Pleistocene to recent volcanism in southern Dominica, Lesser Antilles. J. Volcanol. Geotherm. Res., 148(3-4):253-294. doi:10.1016/ j.jvolgeores.2005.04.018

Machault, J., 2008. Les éruptions ponceuses des volcans actifs de la Guadeloupe et de la Dominique (arc des Petites Antilles). Corrélation entre dépôts à terre et en mer [M.S. thesis]. Univ. d'Orsay, France.

Manga, M., Hornbach, M.J., Le Friant, A., Ishizuka, O., Stroncik, N., Adachi, T., Aljahdali, M., Boudon, G., Breitkreuz, C., Fraass, A., Fujinawa, A., Hatfield, R., Jutzeler, M., Kataoka, K., Lafuerza, S., Maeno, F., Martinez-Colon, M., McCanta, M., Morgan, S., Palmer, M.R., Saito, T., Slagle, A., Stinton, A.J., Subramanyam, K.S.V., Tamura, Y., Talling, P.J., Villemant, B., Wall-Palmer, D., and Wang, F., 2012. Heat flow in the Lesser Antilles island arc and adjacent backarc Grenada basin. Geochem., Geophys., Geosyst., 13:Q08007. doi:10.1029/2012GC004260

Okada, H., and Bukry, D., 1980. Supplementary modification and introduction of code numbers to the low-latitude coccolith biostratigraphic zonation (Bukry, 1973; 1975). Mar. Micropaleontol., 5:321-325. doi:10.1016/ 0377-8398(80)90016-X

Pinel, V., and Jaupart, C., 2000. The effect of edifice load on magma ascent beneath a volcano. Philos. Trans. R. Soc., A, 358(1770):1515-1532. doi:10.1098/rsta.2000.0601

Samper, A., Quidelleur, X., Boudon, G., Le Friant, A., and Komorowski, J.C., 2008. Radiometric dating of three large-volume flank collapses in the Lesser Antilles arc. J. Volcanol. Geotherm. Res., 176(4):485-492. doi:10.1016/ j.jvolgeores.2008.04.018

Thierstein, H.R., Geitzenauer, K.R., Molfino, B., and Shackleton, N.J., 1977. Global synchroneity of late Quaternary coccolith datum levels validation by oxygen isotopes. Geology, 5(7):400-404. doi:10.1130/ 0091-7613(1977)5<400:GSOLQC>2.0.CO;2

Publication: 17 August 2013 MS 340-107 
Figure F1. Site U1397 maps. A. Shaded image of topography-bathymetry, chaotic deposits (interpreted as debris avalanche deposits), and drill sites, Expedition 340. DAD = debris avalanche deposit. (Continued on next page.)

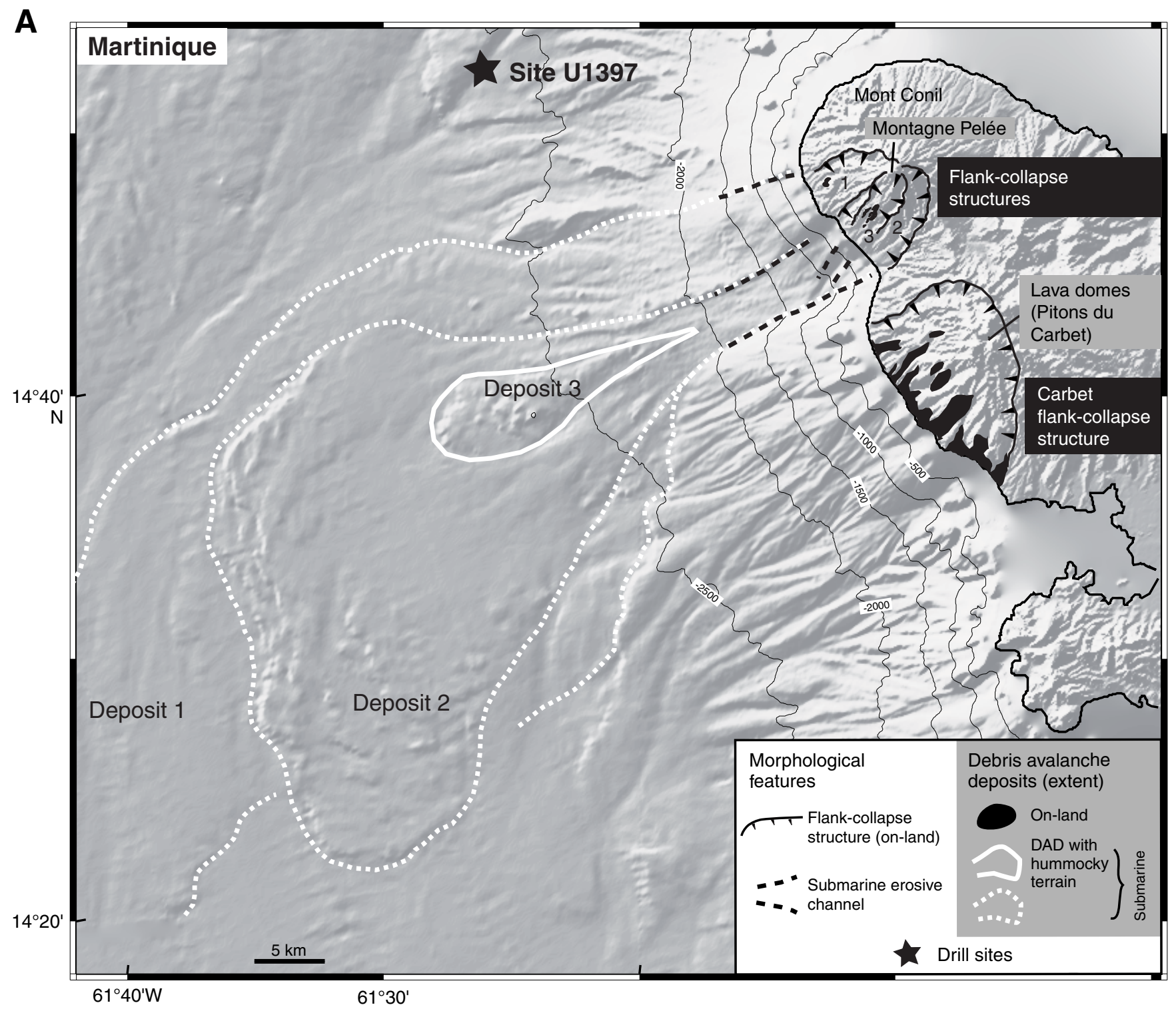


Figure F1 (continued). B. Location of seismic reflection lines across Site U1397. CDP = common depth point.

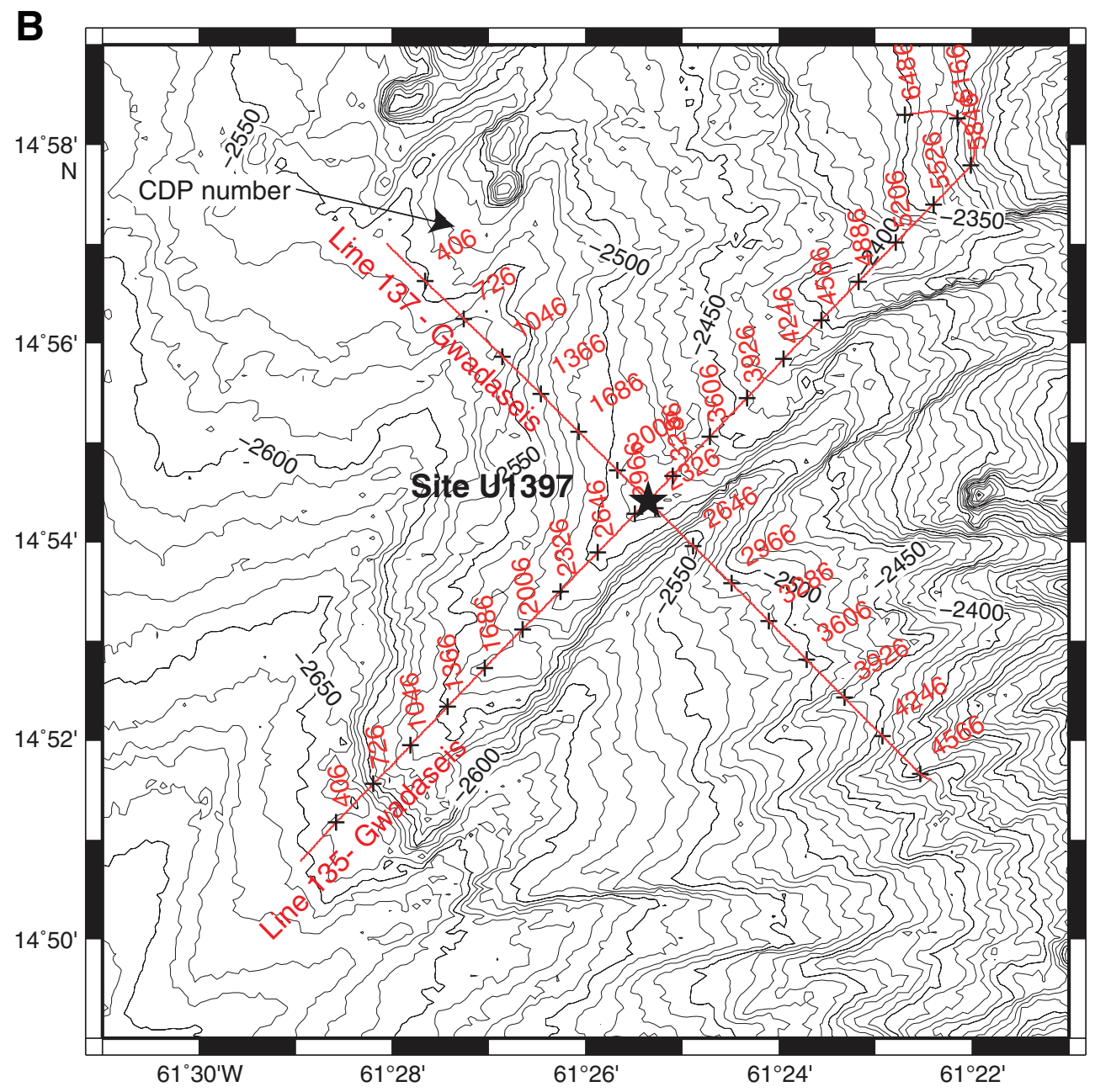


Figure F2. Integrated nannofossil and planktonic foraminiferal biozonation, Site U1397.

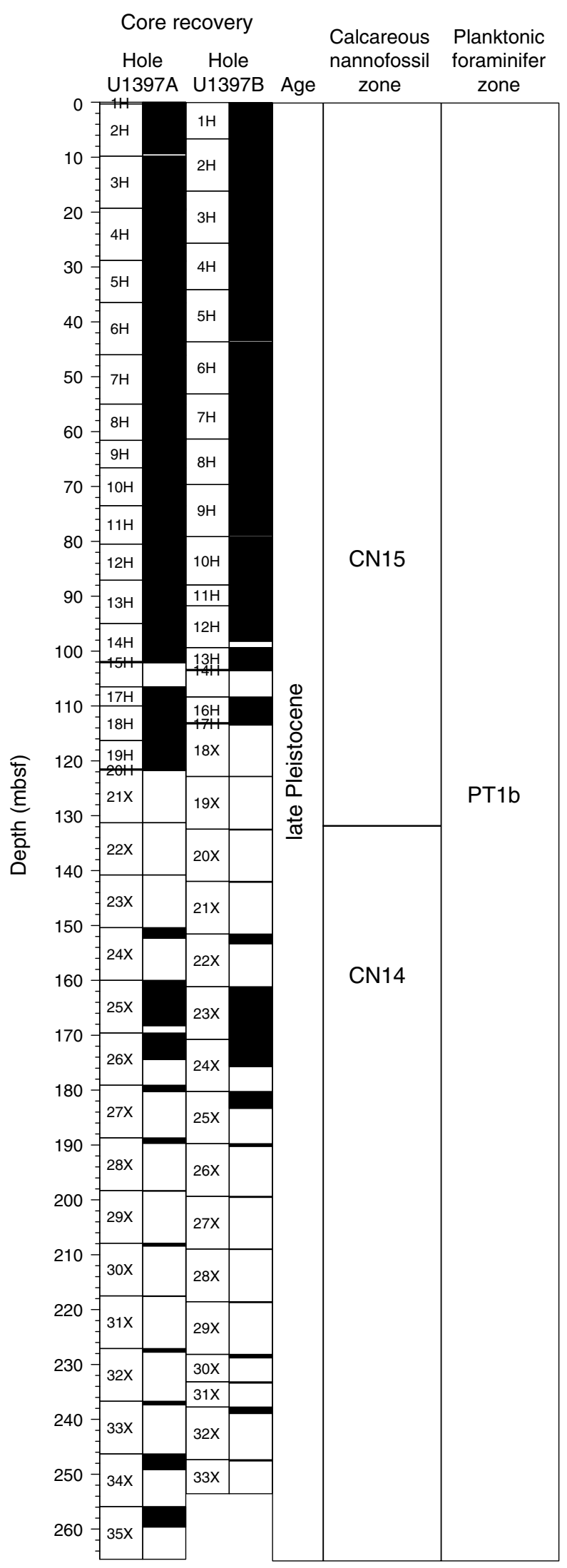


Figure F3. Biostratigraphic age model for Hole U1397A. Blue line denotes maximum age from reliable biostratigraphic data. Red line denotes minimum age from reliable biostratigraphic data. Thin black line denotes foraminiferal secondary marker species range. Green line denotes nannofossil species range. Gray box denotes the depth of turbidites within the core.

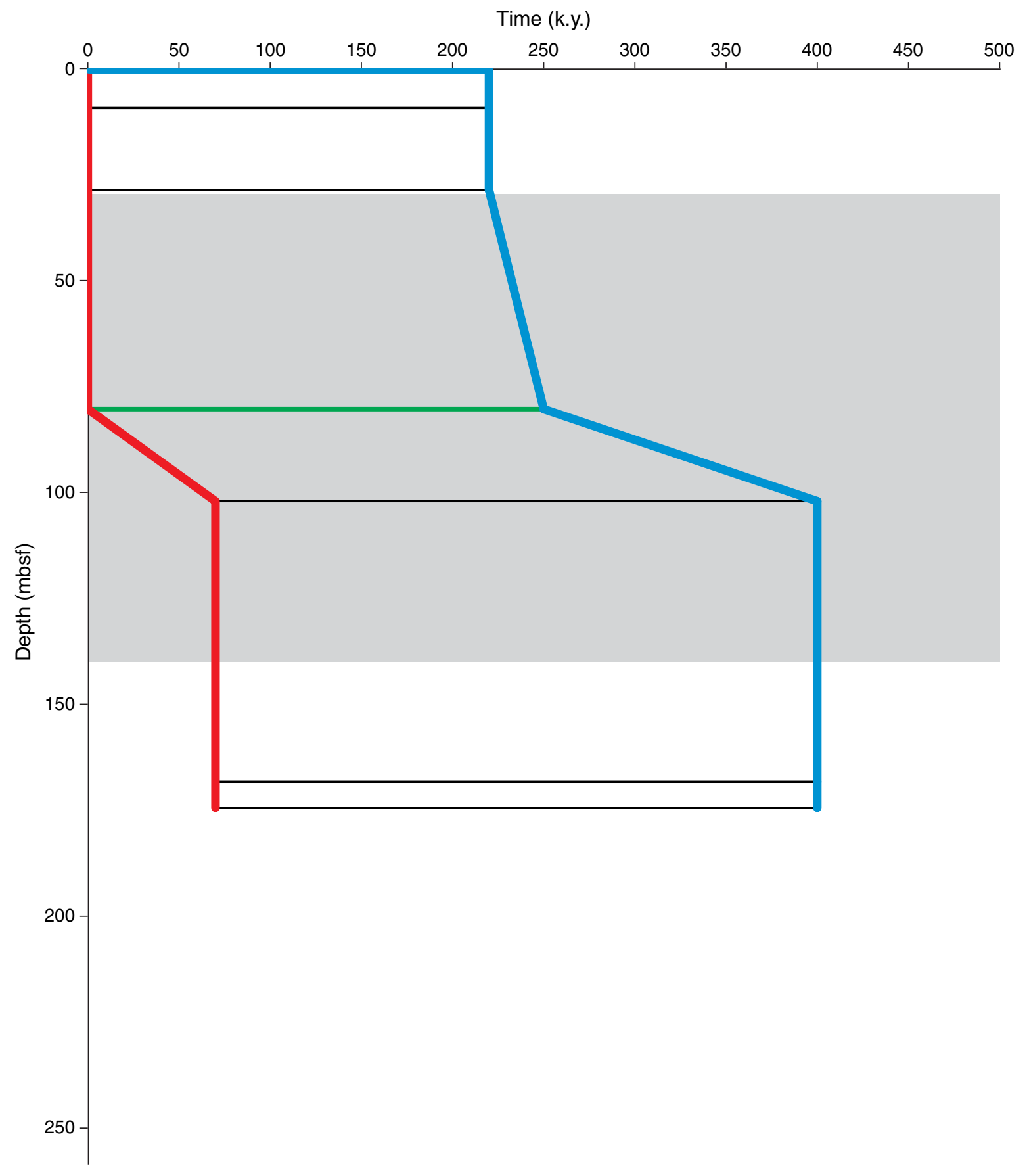


Figure F4. Biostratigraphic age model for Hole U1397B. Blue line denotes maximum age from reliable biostratigraphic data. Red line denotes minimum age from reliable biostratigraphic data. Thin black line denotes foraminiferal secondary marker species range. Green line denotes nannofossil species range. Thick black line denotes clasts from the Piton du Carbet volcano. Gray box denotes the depth of turbidites within the core.

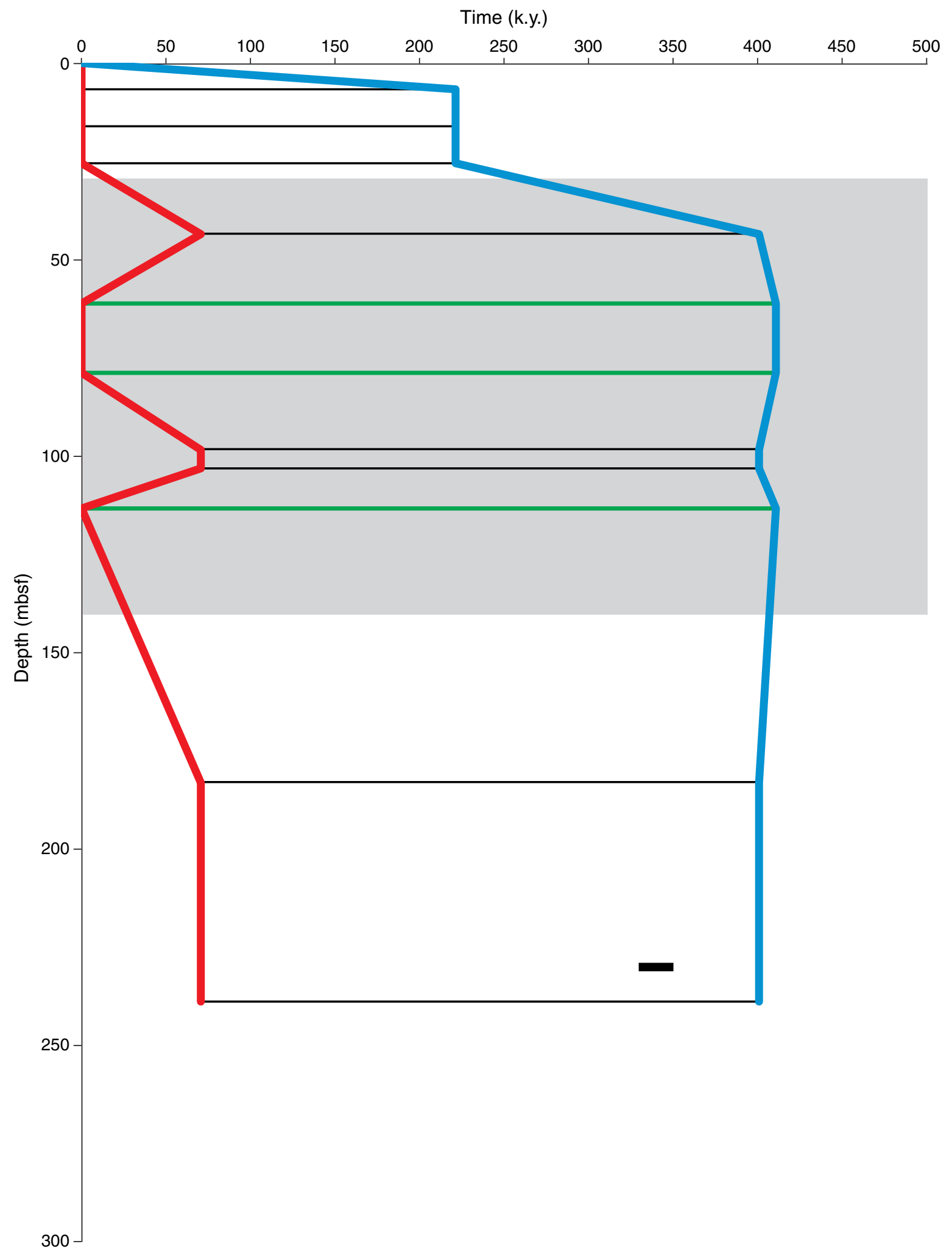


Figure F5. Composite age model for Site U1397. Red line denotes maximum age described by only biostratigraphy. Blue line denotes maximum age described by biostratigraphy and volcanic clasts. Lines at an angle are a linear interpolation between two data points. Gray box denotes the depth of turbidites within the core.

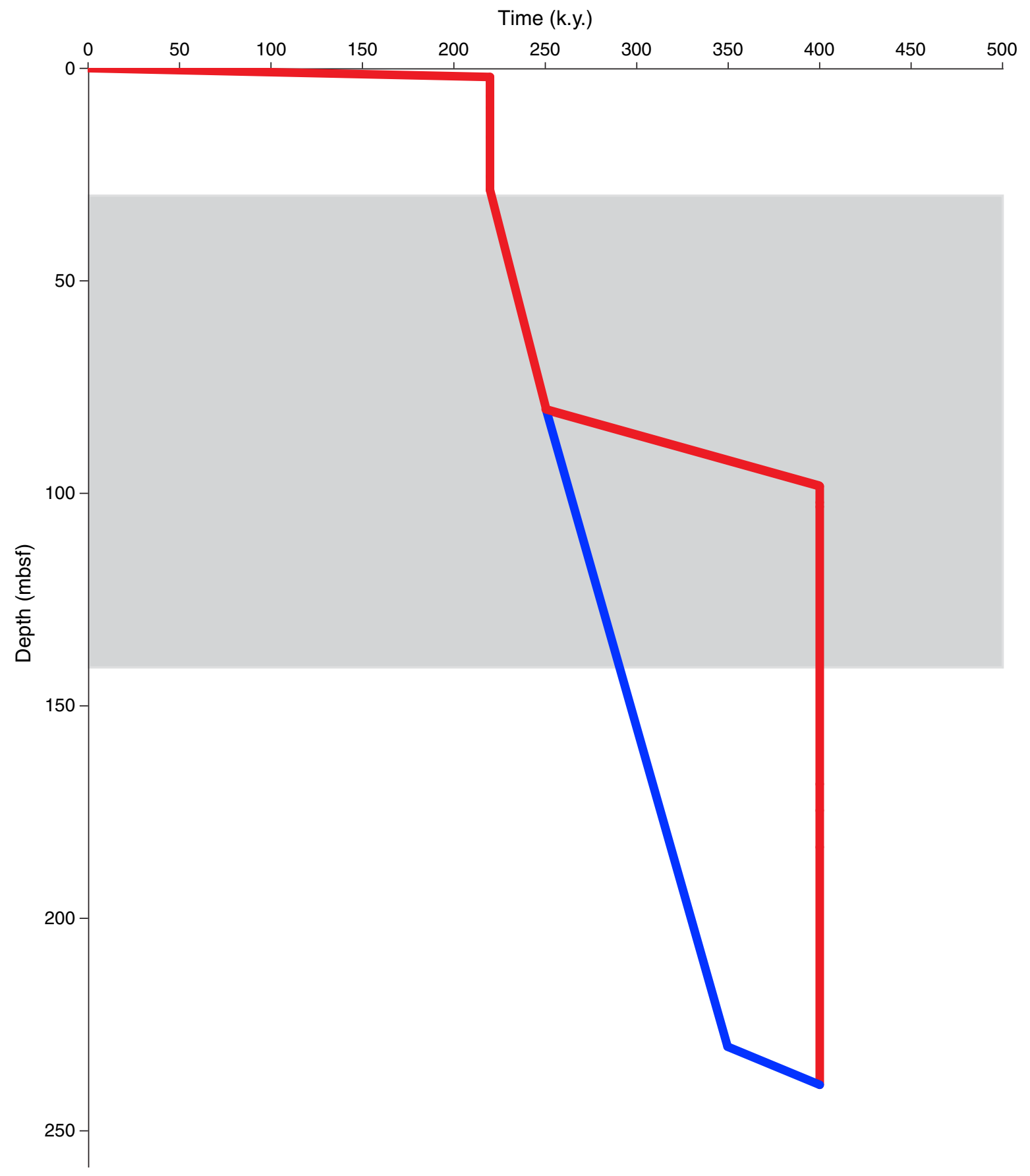




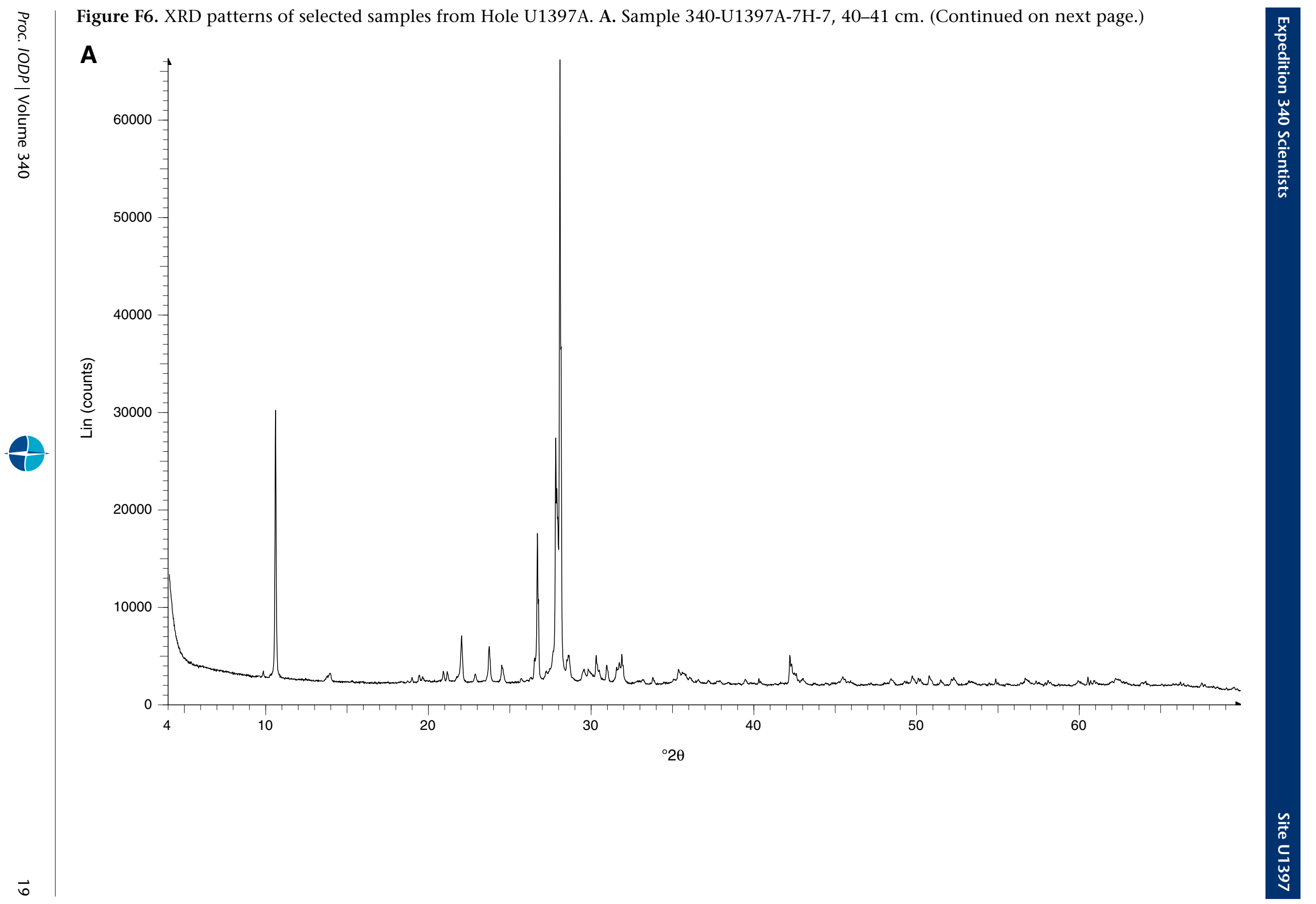




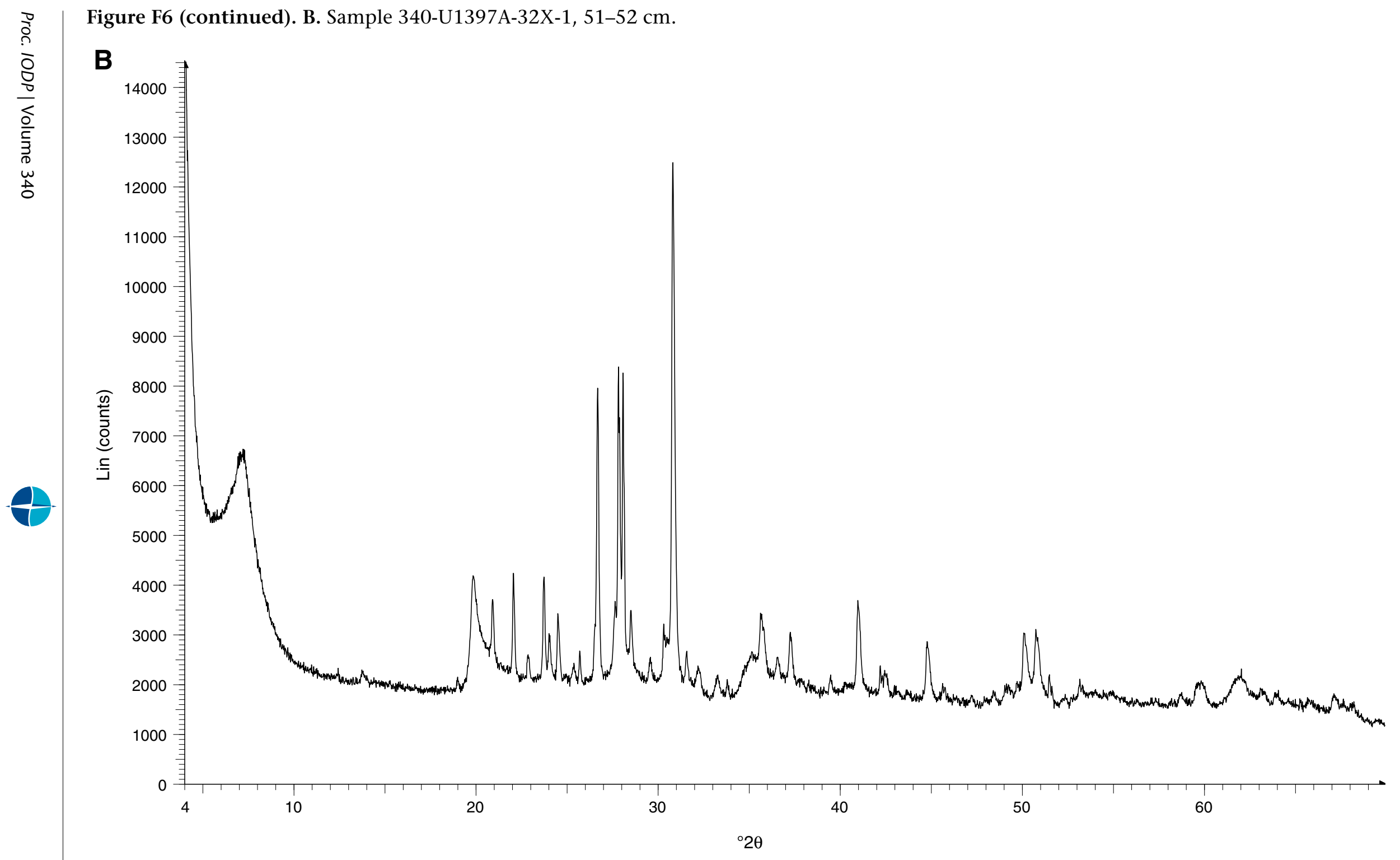


Figure F7. Solid phase $\mathrm{CaCO}_{3}$ depth profile, Site U1397.

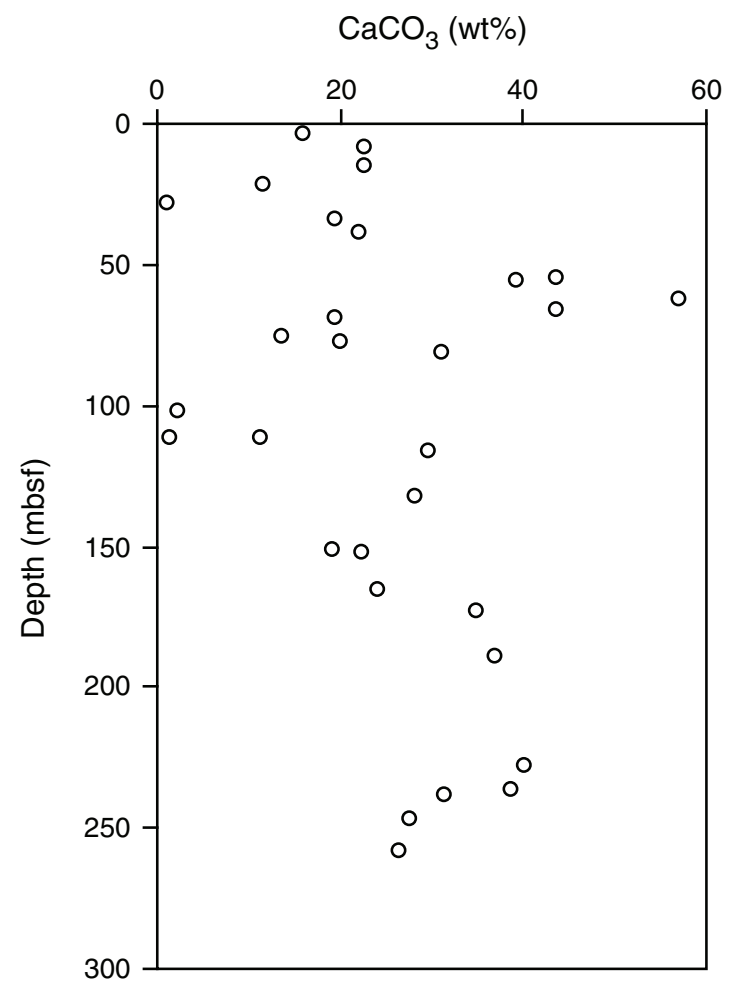




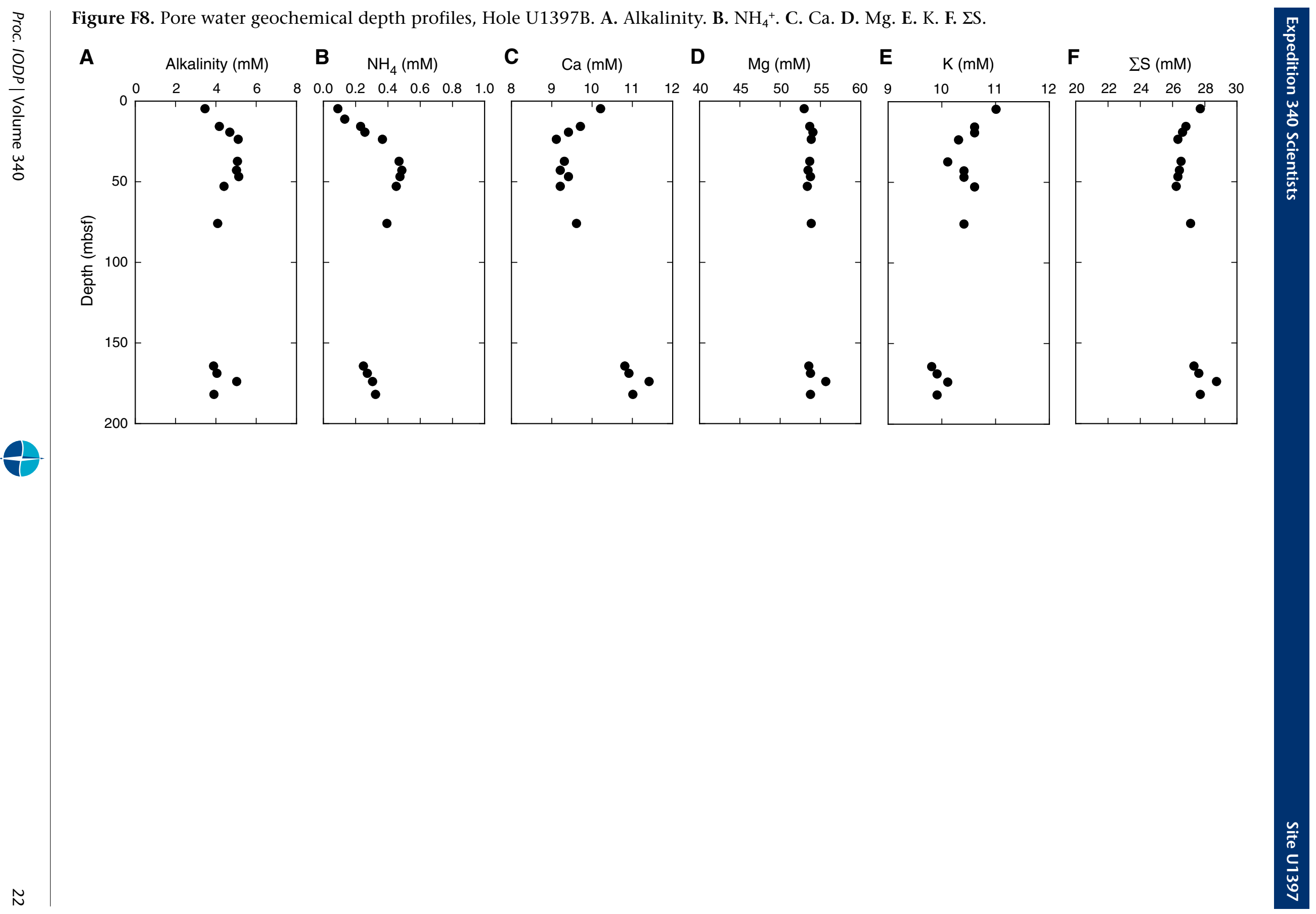


Figure F9. Natural gamma radiation (NGR) correlation, Hole U1397B (blue) to Hole U1397A (red). Negative values in the last column indicate a downhole shift. A. 0-25 mbsf. (Continued on next page.)
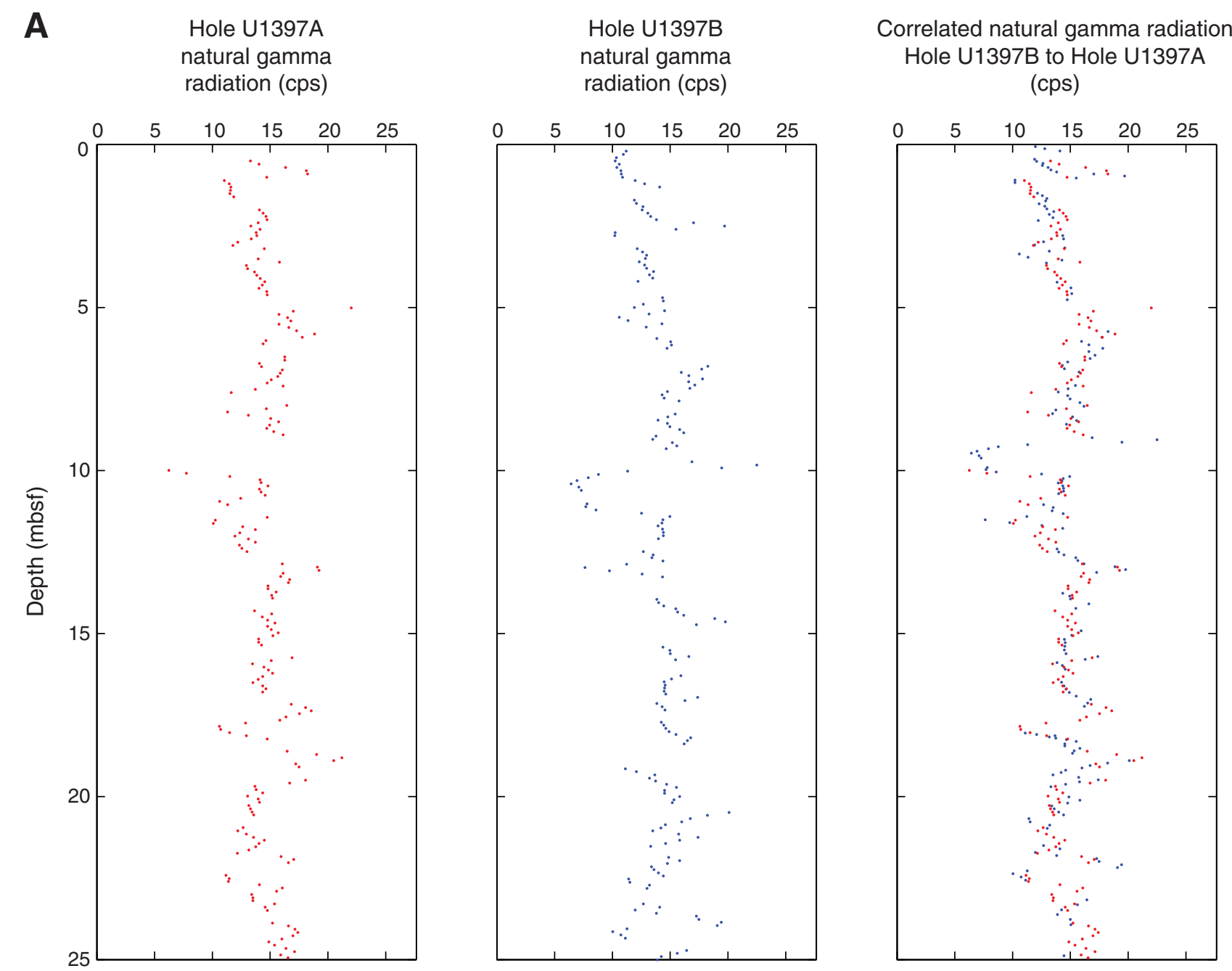

Hole U1397B shift in depth

(m)

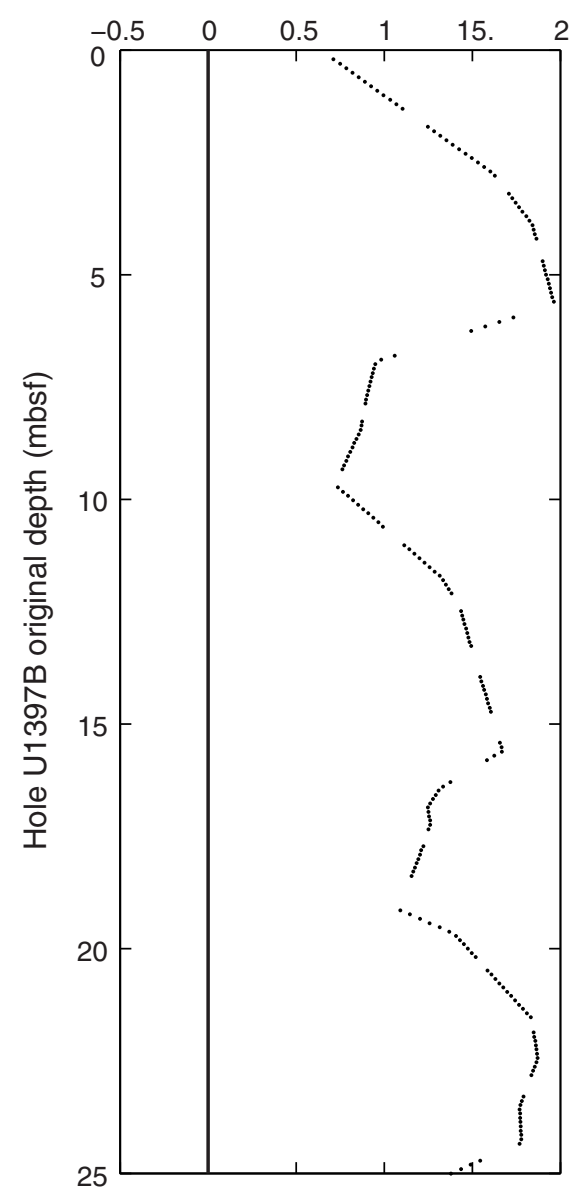



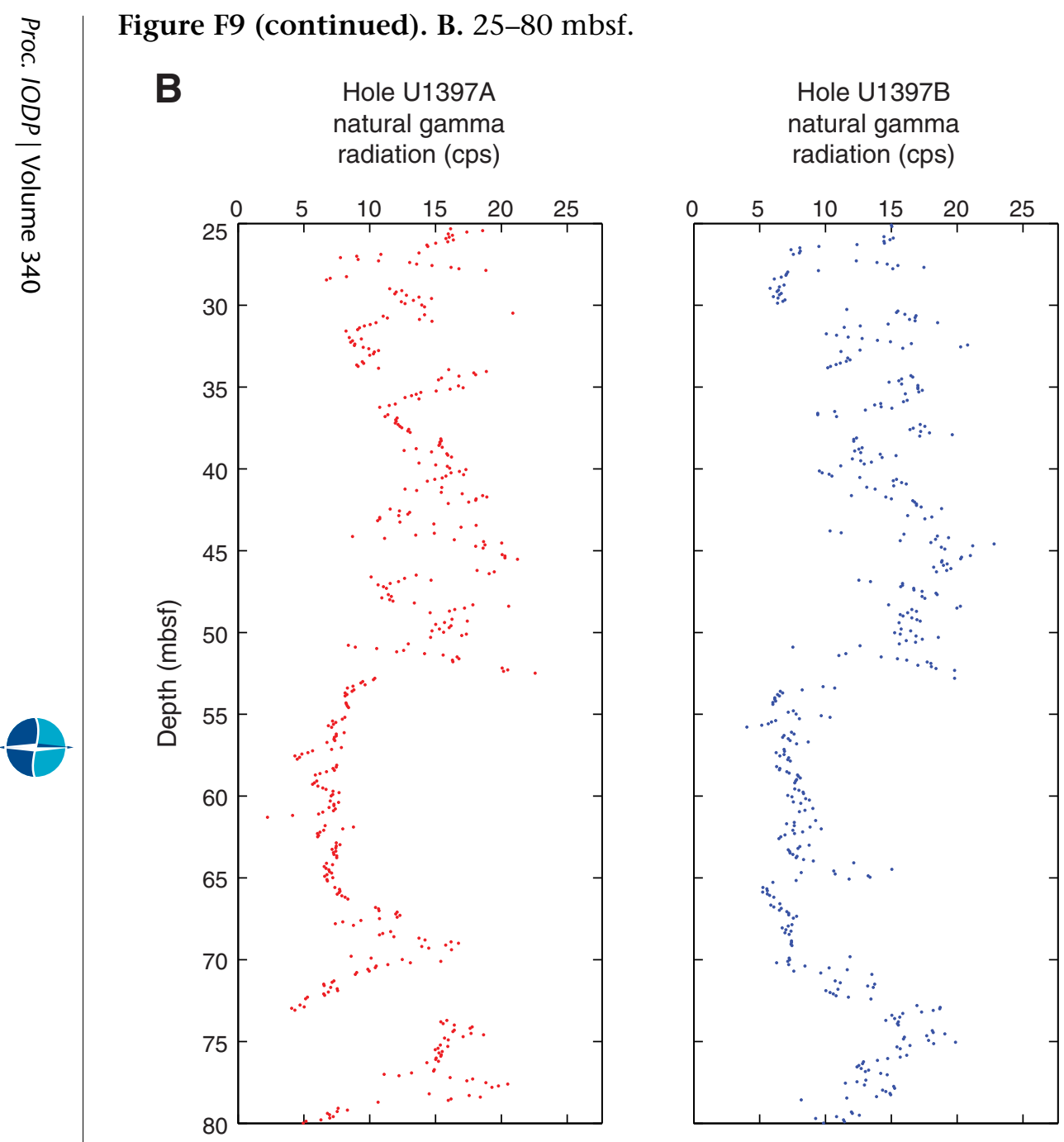

Correlated natural gamma radiation Hole U1397B to Hole U1397A (cps)

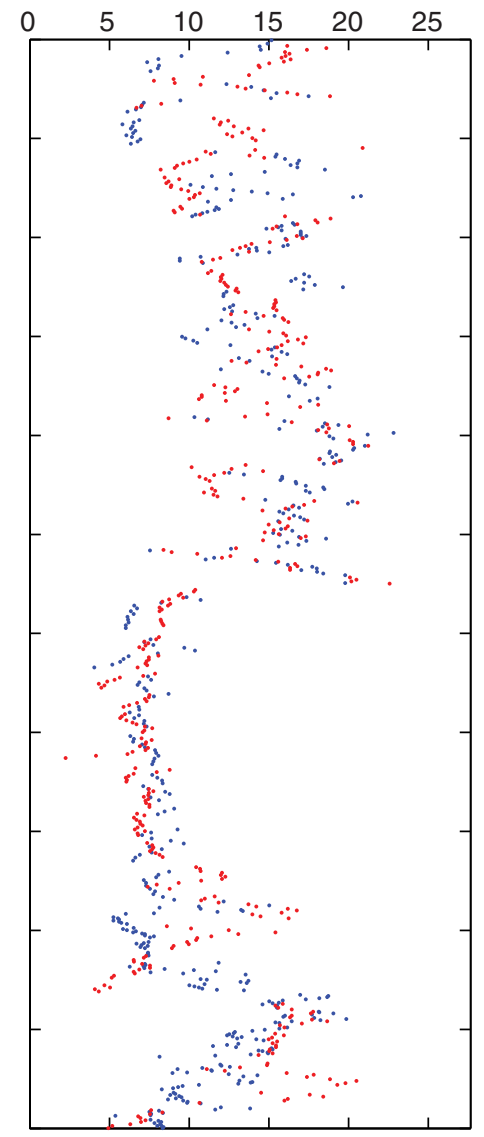

Hole U1397B shift in depth

(m)

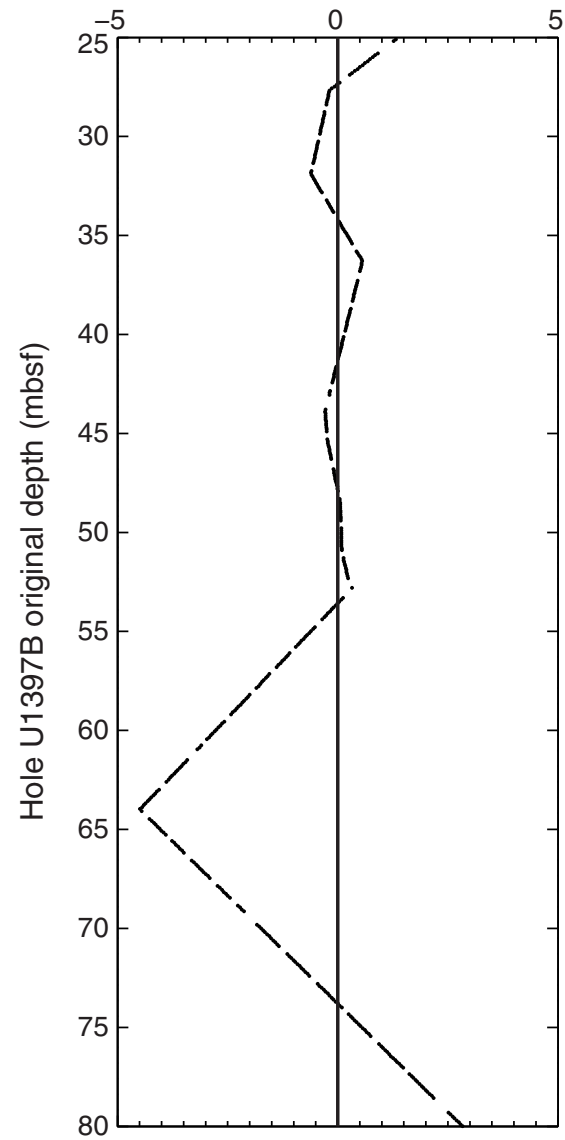


Figure F10. Physical properties, Holes U1397A (red) and U1397B (blue). AVS = automated vane shear. Small points indicate measurements on whole cores using the Whole-Round Multisensor Logger (WRMSL) or Natural Gamma Radiation Logger (NGRL). Larger circles indicate spot measurements obtained from samples of the split working half of the core. A. 0-120 mbsf. (Continued on next page.)
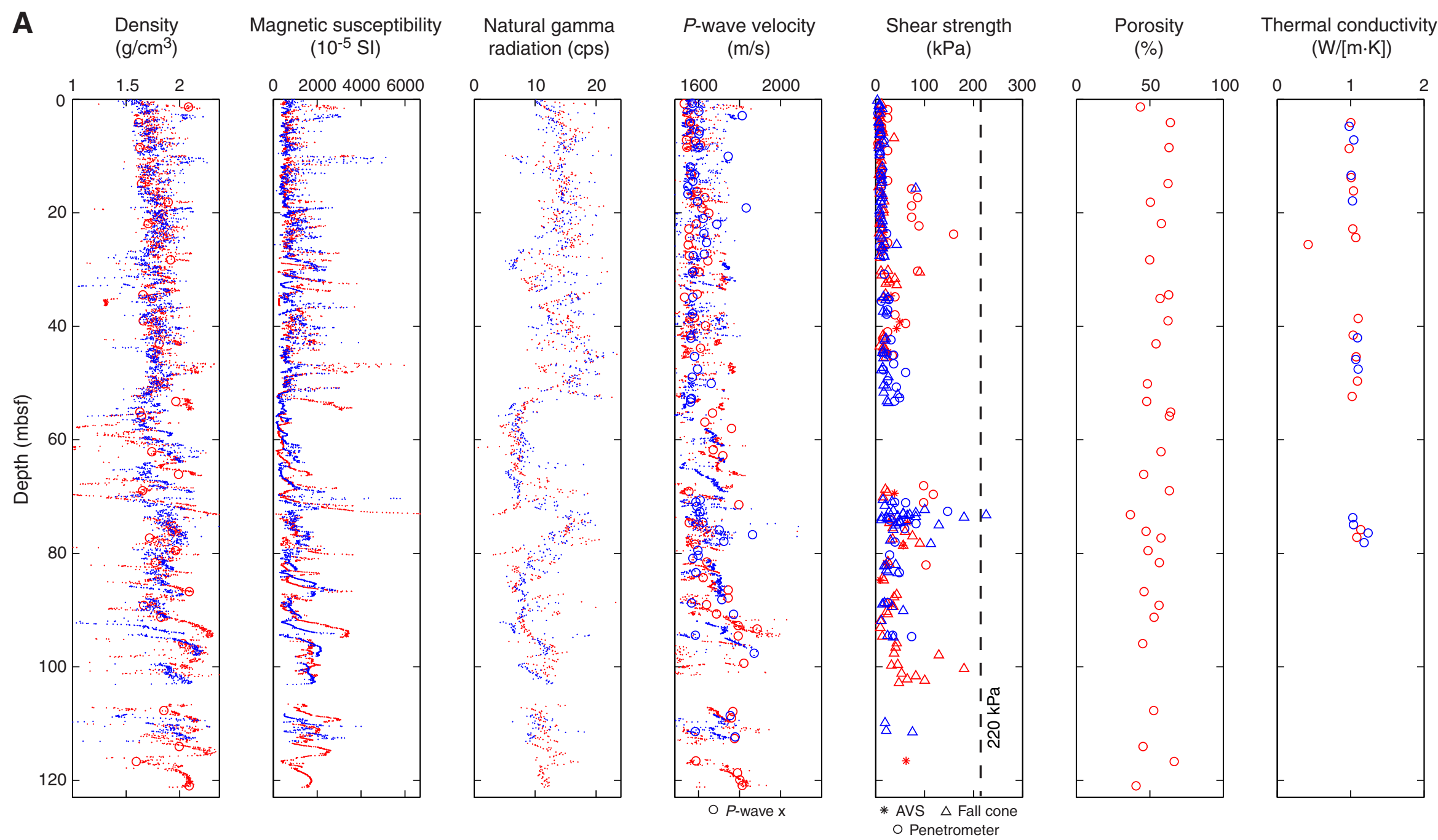


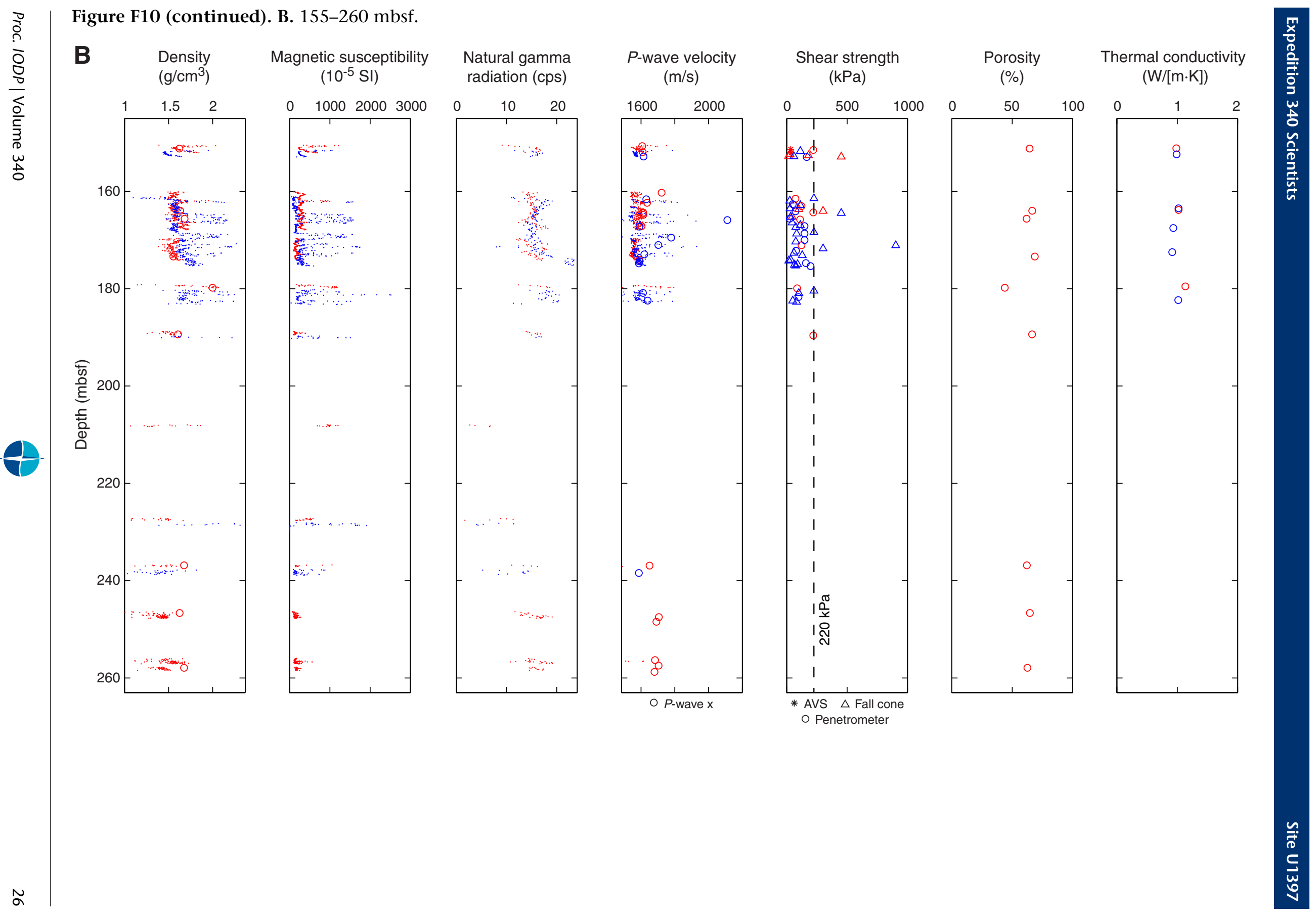


Figure F11. Temperature as a function of depth, Holes U1397A (red) and U1397B (blue). Straight line is a best fit to the measurements.

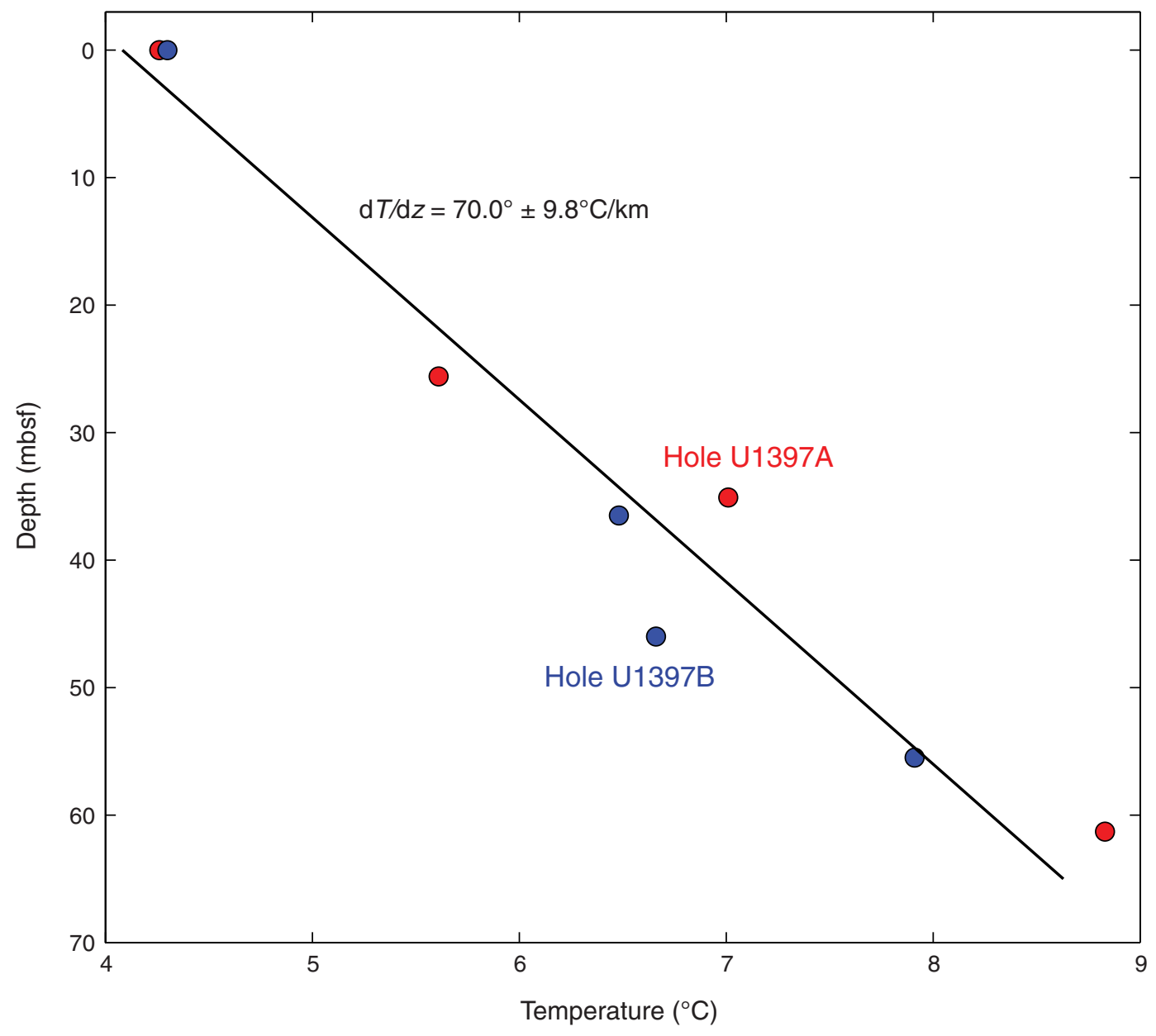


Figure F12. Plots of intensity of $\mathrm{NRM}_{0}$ (red) and $\mathrm{NRM}_{20}$ (blue) and inclination and declination after $20 \mathrm{mT}$ demagnetization, Hole U1397A. For inclination data, gray points are all measurements made and red data are measurements made on hemipelagic sediment. For declination data, gray points are unoriented declinations and red points are FlexIt tool-corrected data on hemipelagic sediment. Black squares are discrete declination and inclination measurements shown against a geocentric axial dipole (GAD) inclination of $28.0^{\circ}$.

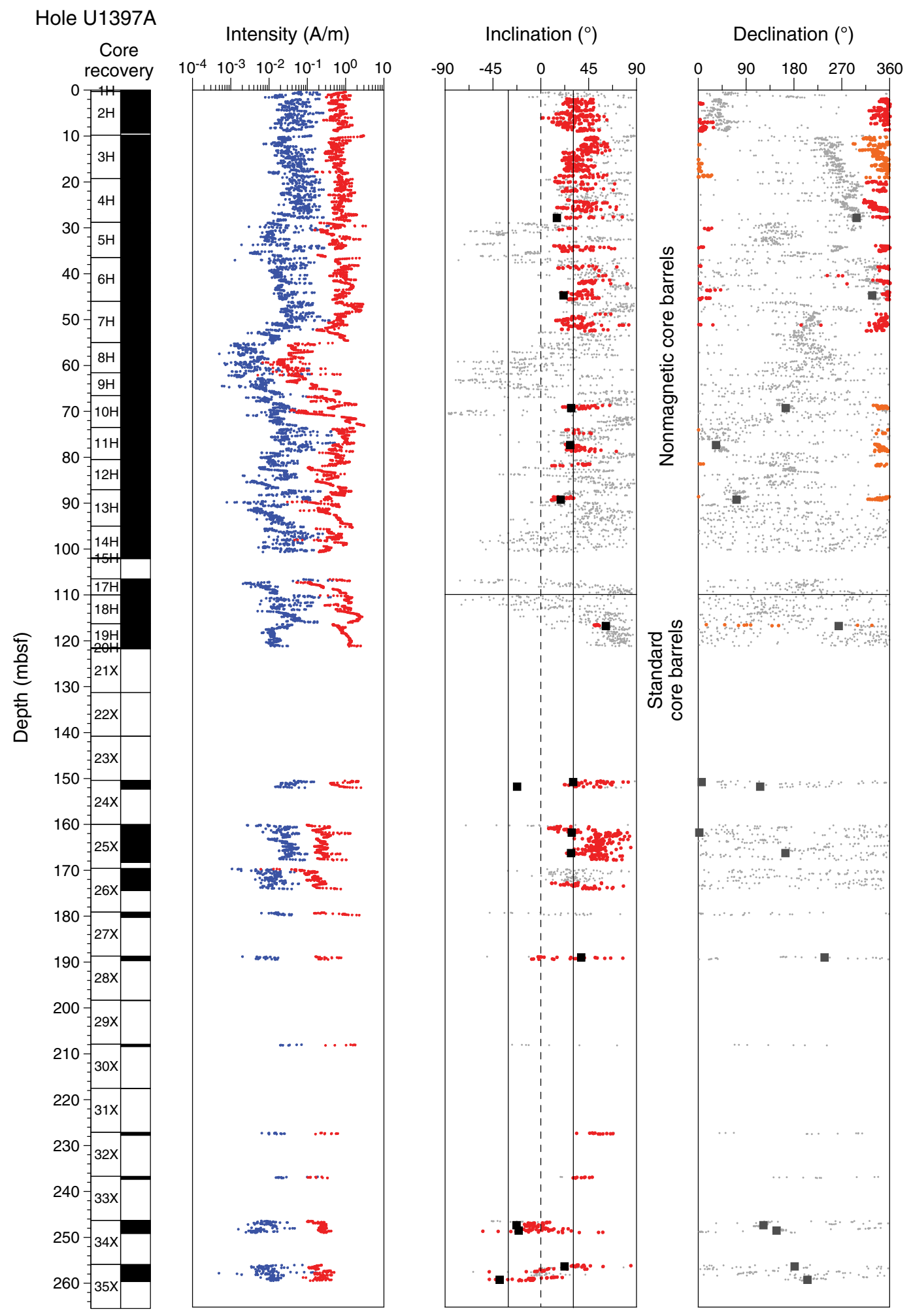


Figure F13. Plots of intensity of $\mathrm{NRM}_{0}$ (red) and $\mathrm{NRM}_{20}$ (blue) and inclination and declination after $20 \mathrm{mT}$ demagnetization, Hole U1397B. For inclination data, gray points are all measurements made and red data are measurements made on hemipelagic sediment. For declination data, gray points are unoriented declinations and orange points are from hemipelagic sediments rotated and guided by discrete inclination data. Black squares are discrete declination and inclination measurements shown against a geocentric axial dipole (GAD) inclination of $28.0^{\circ}$.

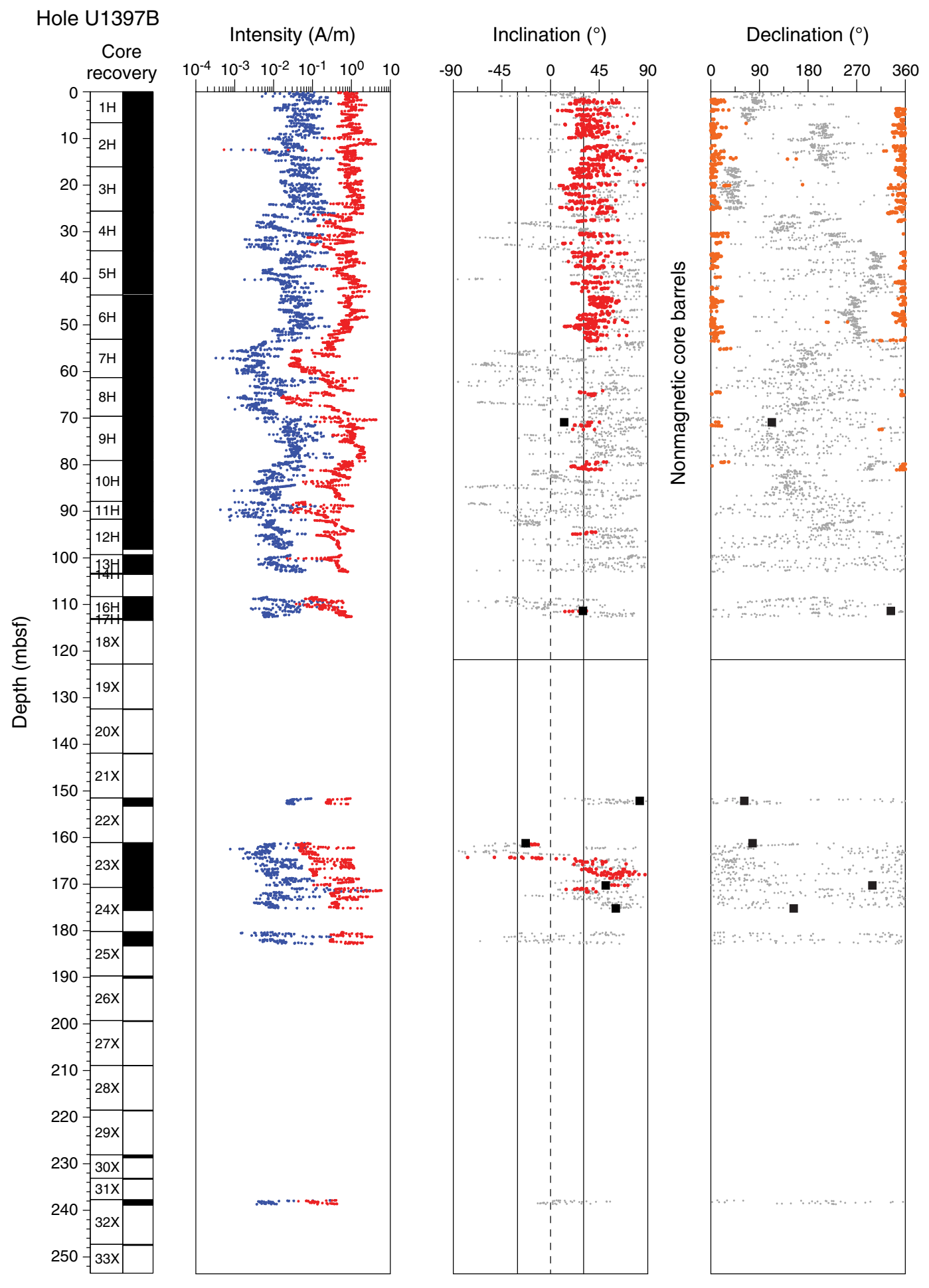


Figure F14. Schematic of tool deployments in Hole U1397B, indicating the degree of infill through the course of the logging program. MSS = Magnetic Susceptibility Sonde, FMS = Formation MicroScanner.

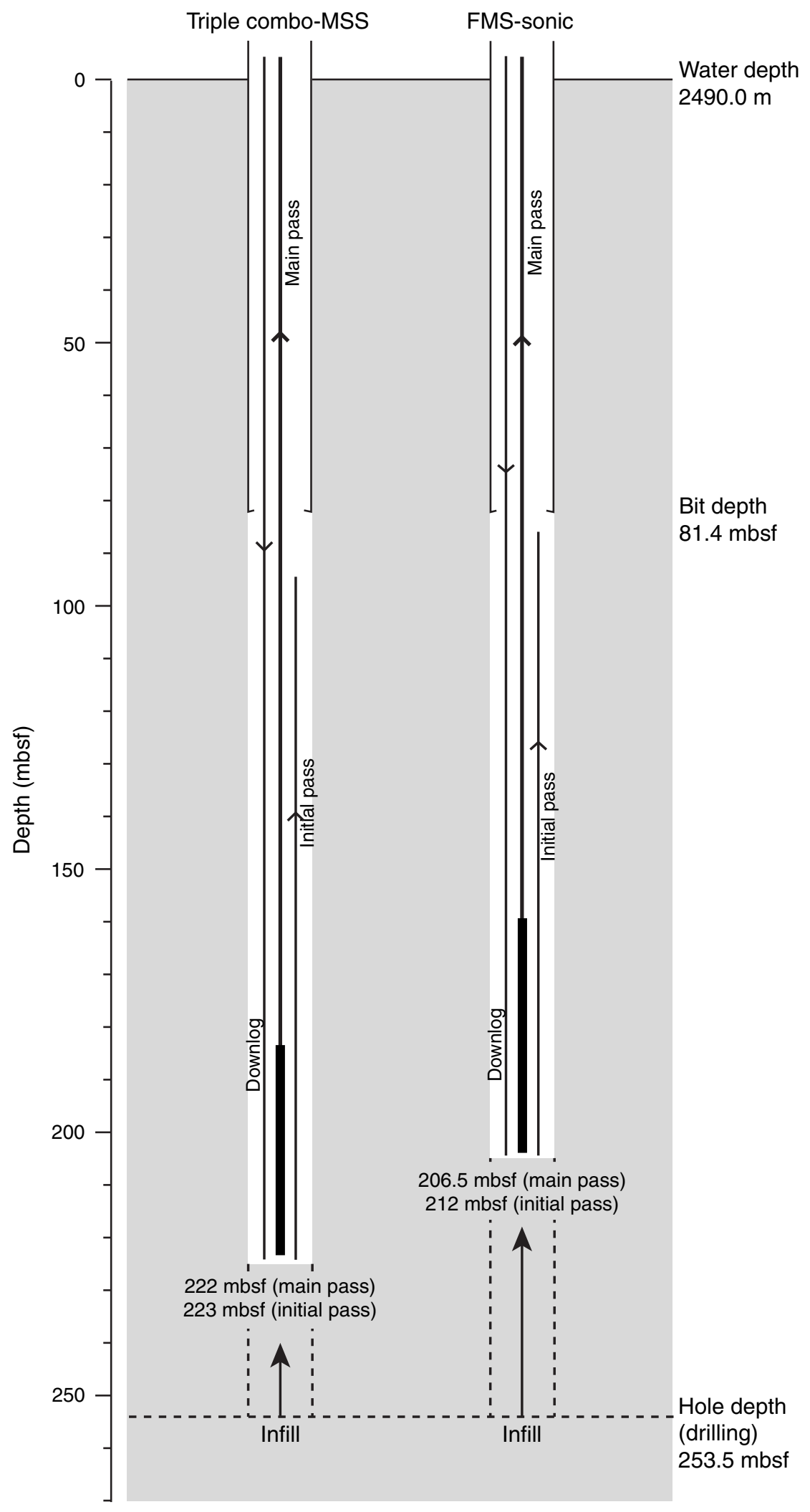


Figure F15. Summary of logs recorded by the triple combo and comparison to physical properties measured on recovered cores, Hole U1397B. NGR = natural gamma radiation measured from cores. High-Resolution Laterolog Array (HRLA) readings: R3 = medium resistivity, R5 = deepest resistivity, RT = true resistivity, modeled from all depths of investigation. uncal $=$ uncalibrated units.

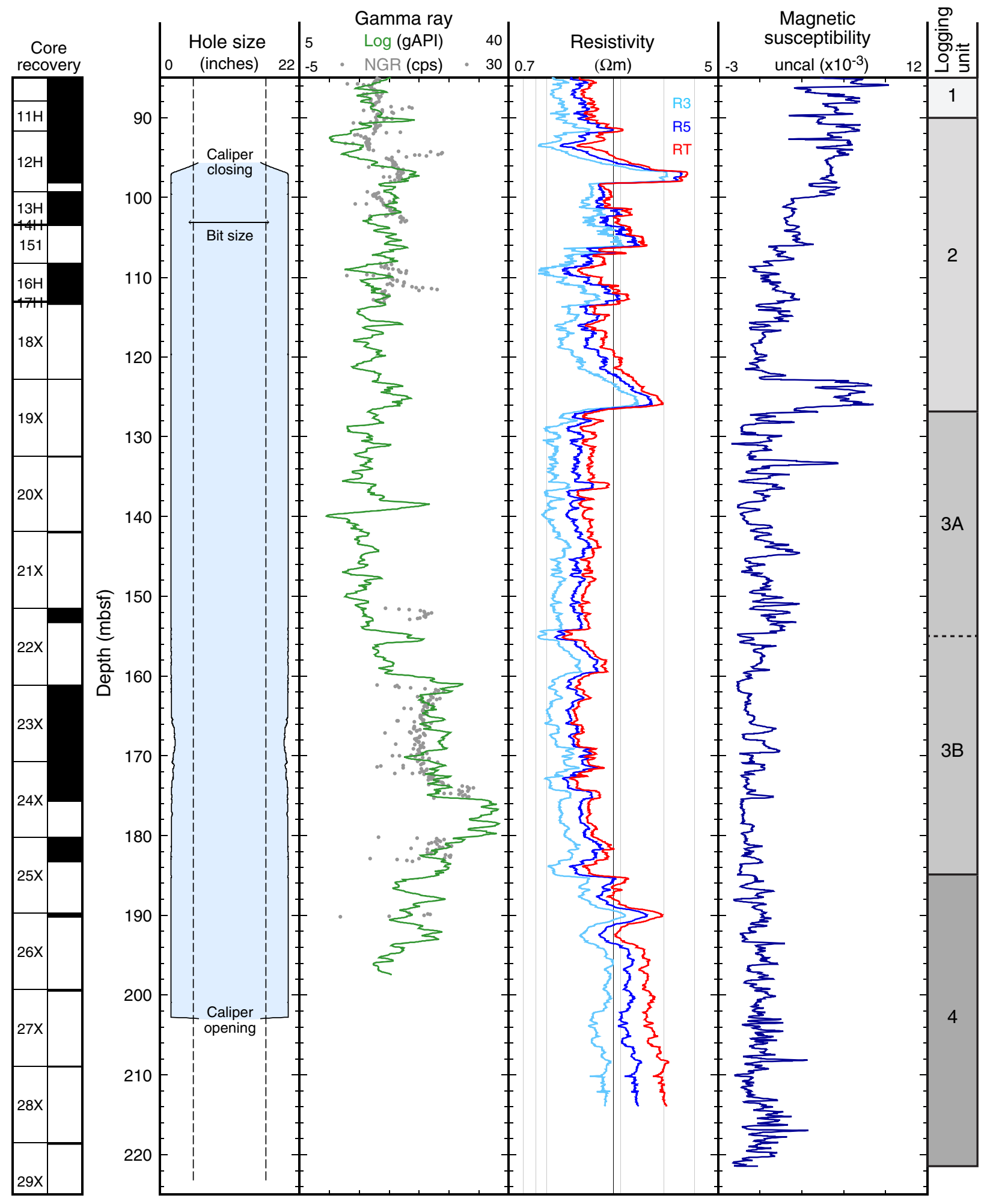


Figure F16. Summary of logs recorded by the Formation MicroScanner (FMS)-sonic tool string, Hole U1397B. Hole size is measured by the two orthogonal calipers of the FMS (C1 and C2). Gamma ray recorded during the FMS-sonic run (FMS) is compared to gamma ray recorded by the triple combo run (TC). The high waveform coherence, in red in the velocity tracks, is a measure of the reliability of the slowness/time coherence algorithm used to derive compressional $\left(V_{\mathrm{P}}\right)$ and shear $\left(V_{S}\right)$ wave velocities from the monopole and lower dipole sonic waveforms, respectively.

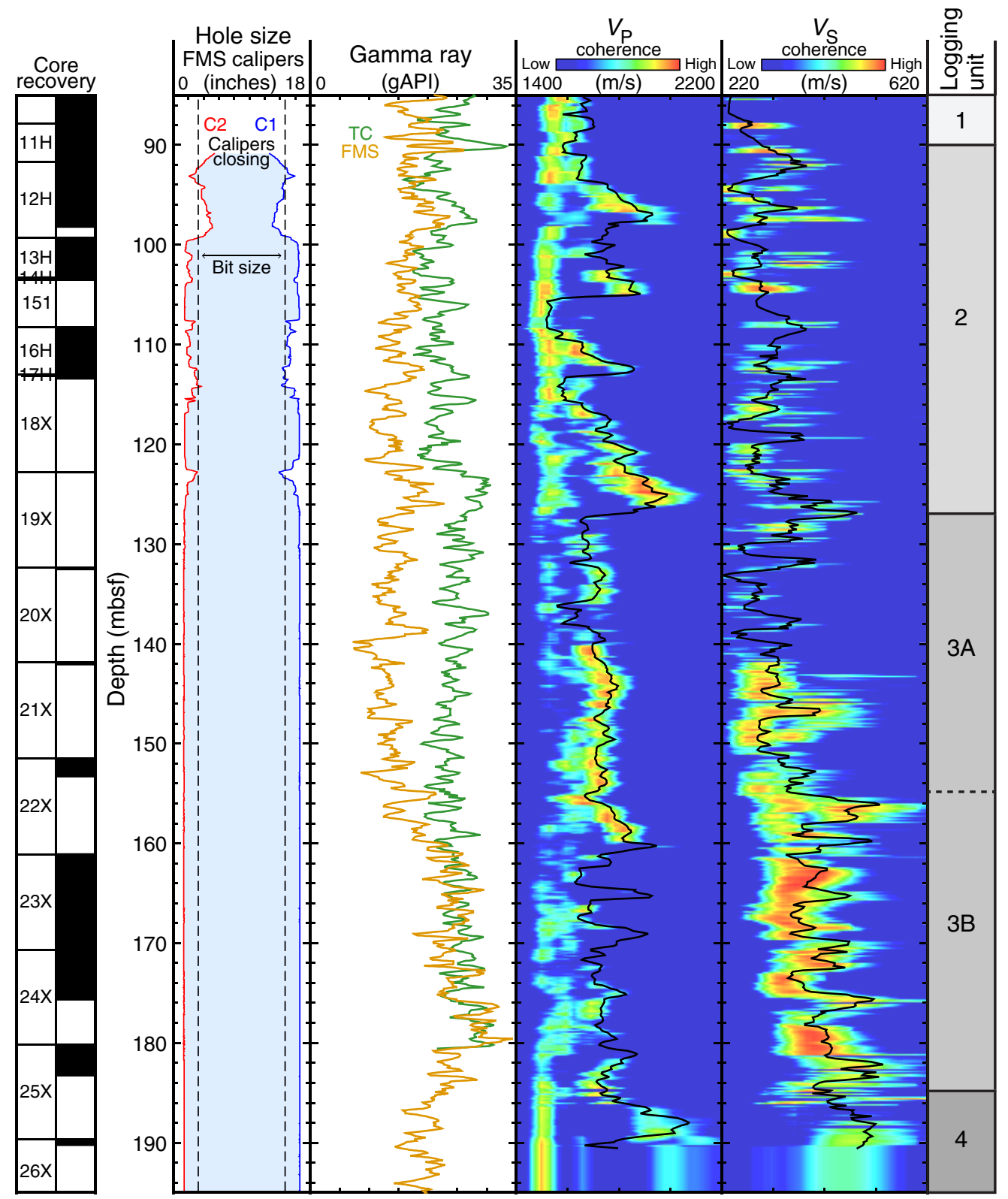


Figure F17. Summary of spectral natural gamma radiation measurements, Hole U1397B. SGR = total gamma ray, $\mathrm{CGR}=$ computed gamma ray or gamma ray without the contribution of uranium. The area between the two curves shows the contribution of uranium, a common indicator of organic content.

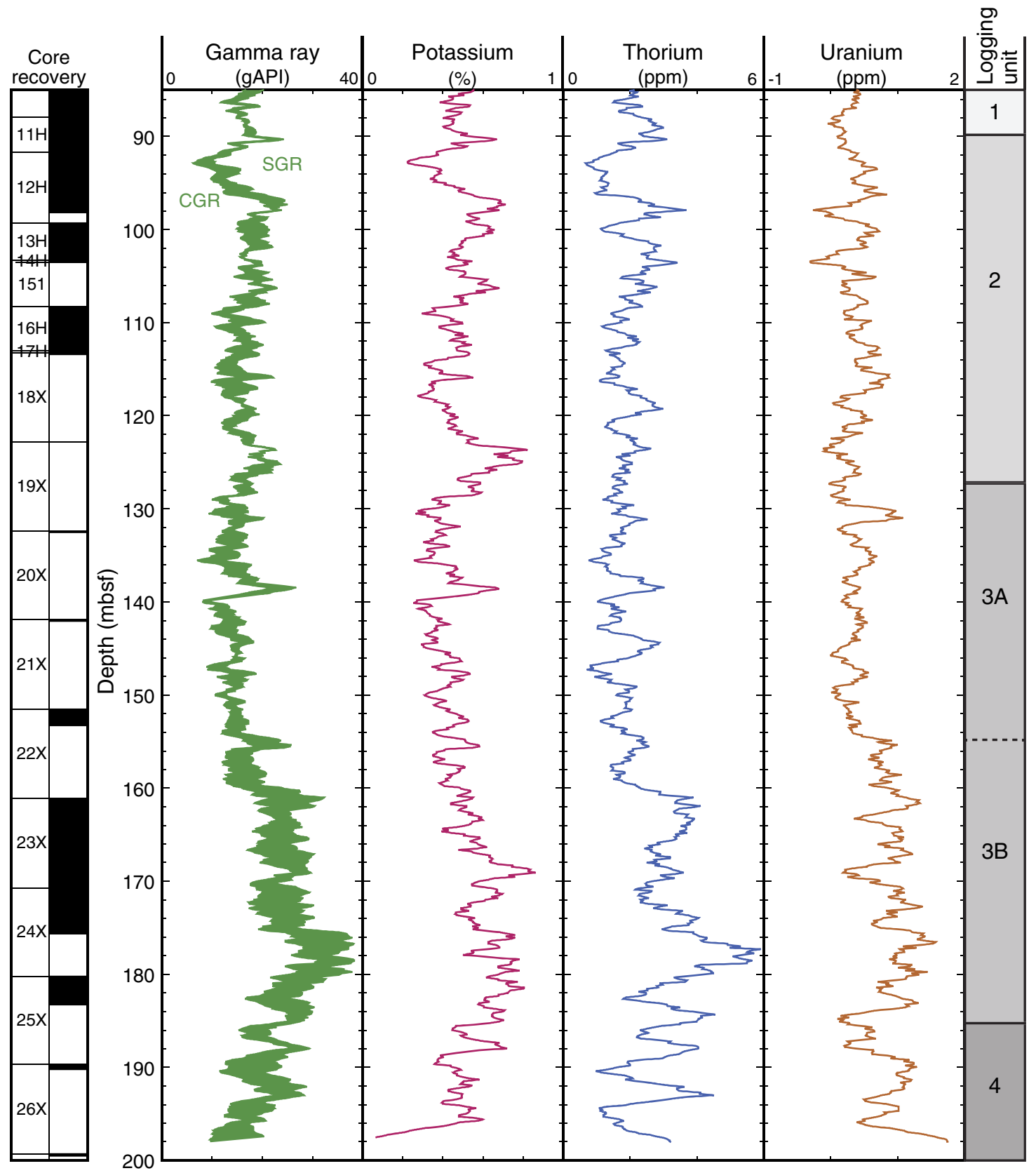


Figure F18. Comparison of some of the main logs recorded during multiple logging passes, Hole U1397B. There is generally good agreement between the two passes, indicating the reliability of the various measurements. The exception to this is where the gamma ray curves on subsequent passes are offset below 160 mbsf. uncal = uncalibrated units.

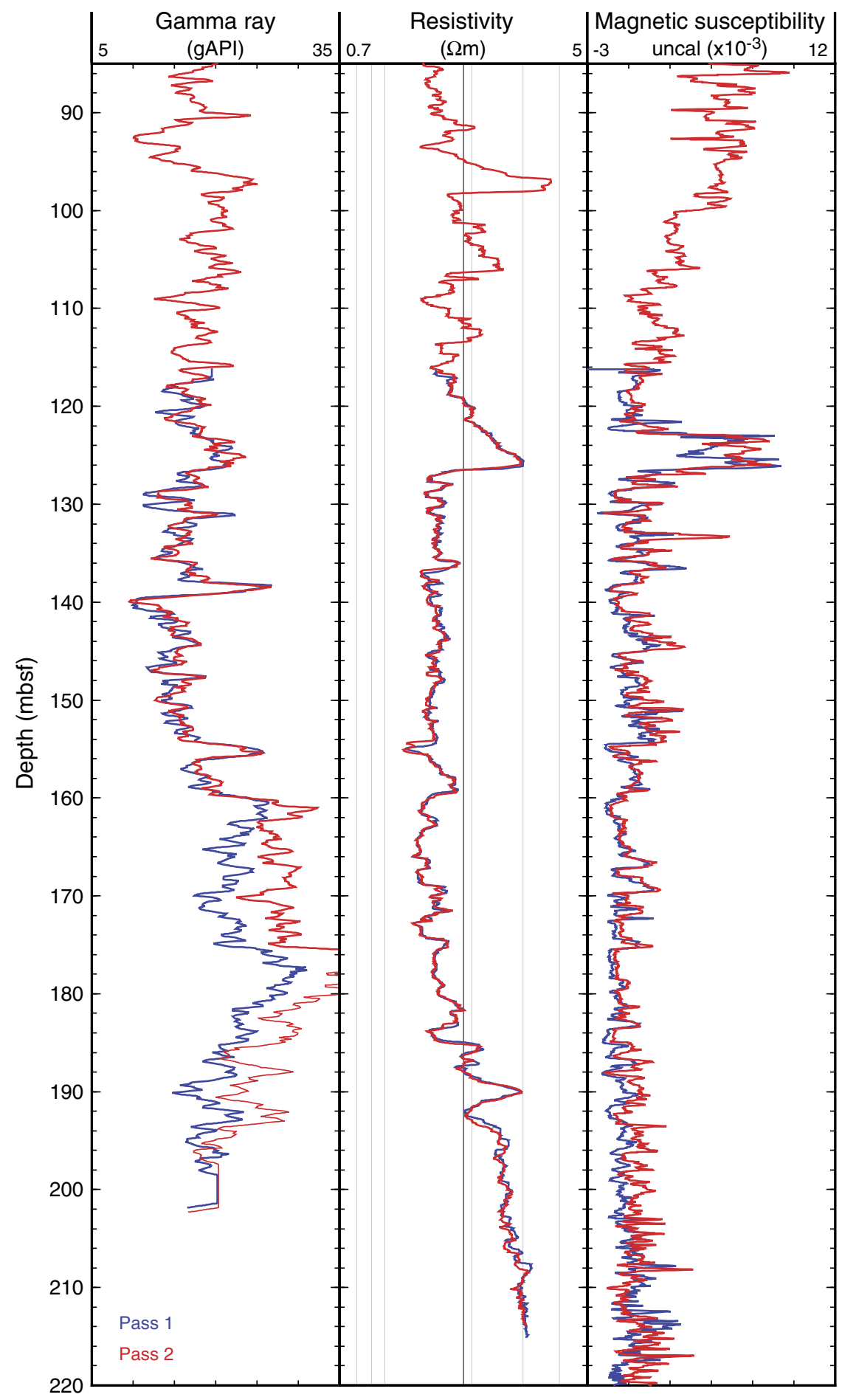


Figure F19. Example of dynamically processed FMS image, Hole U1397B. Image is of a small interval where borehole diameter was small enough to capture some of the electrical properties of the borehole wall. It is shown with the corresponding core, which indicates a distinct change in lithology. This lithological change is not captured in the FMS image but is, however, echoed in the equivalent resistivity log (detail from Fig. F15).

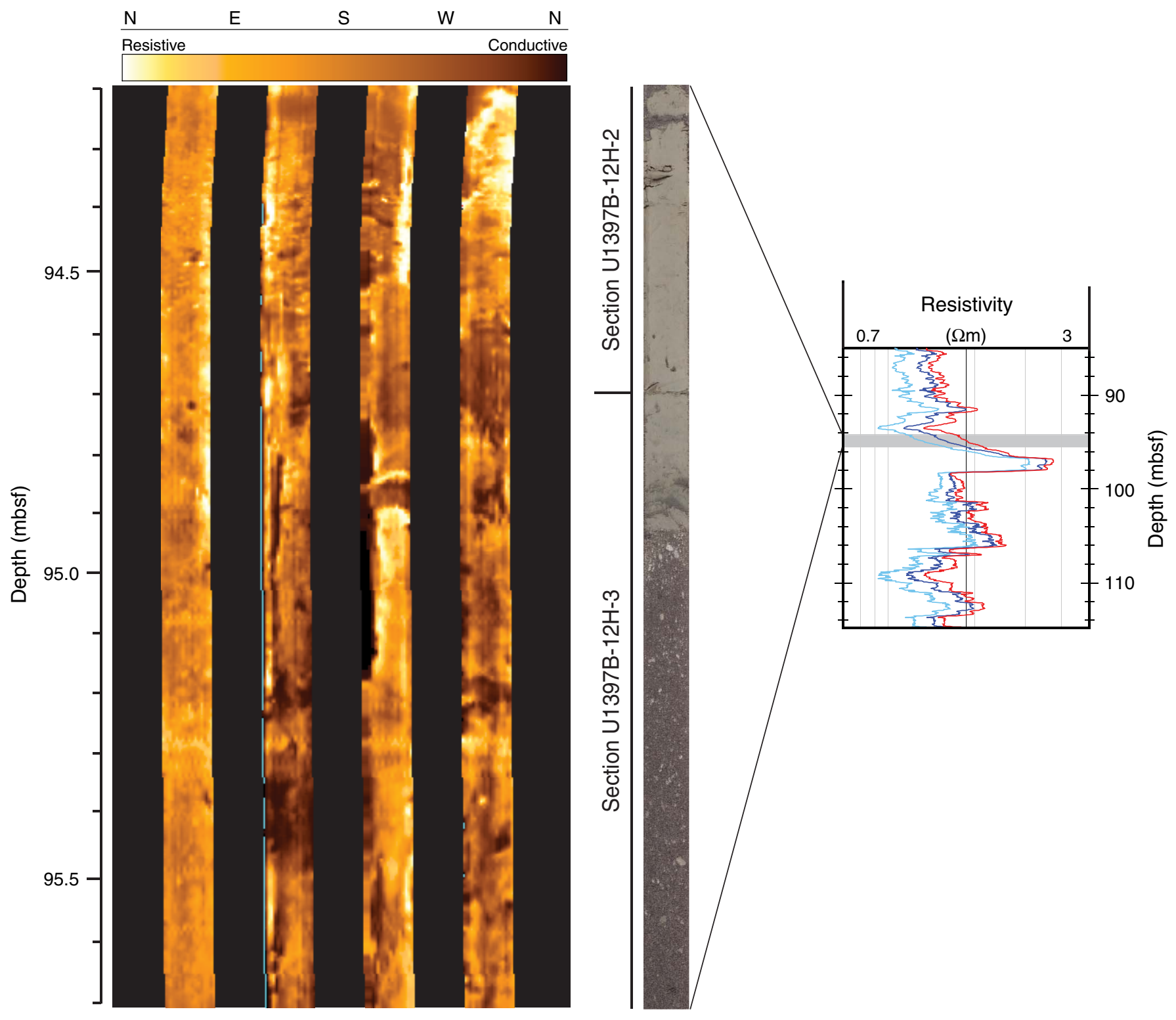


Table T1. Coring summary, Site U1397. (Continued on next page.)

\begin{tabular}{|c|c|}
\hline Hole: & U1397A \\
\hline Latitude: & $14^{\circ} 54.4081^{\prime} \mathrm{N}$ \\
\hline Longitude: & $61^{\circ} 25.3530^{\prime} \mathrm{W}$ \\
\hline Water depth (m): & 2482.2 \\
\hline Date started (UTC*): & 1545 h 18 March 2012 \\
\hline Date finished $\left(\right.$ UTC $\left.^{*}\right)$ : & 2100 h 20 March 2012 \\
\hline Time on hole (days): & 2.2 \\
\hline Seafloor depth DRF $(m)$ : & 2493.7 \\
\hline Penetration DSF (m): & 265.5 \\
\hline Cored interval $(\mathrm{m})$ : & 261.1 \\
\hline Recovered length (m): & 144.20 \\
\hline Recovery (\%): & 55 \\
\hline Drilled interval $(\mathrm{m})$ : & 4.4 \\
\hline Drilled interval (no.): & 1 \\
\hline Total cores (no.): & 34 \\
\hline Hole: & U1397B \\
\hline Latitude: & $14^{\circ} 54.4075^{\prime} \mathrm{N}$ \\
\hline Longitude: & $61^{\circ} 25.3421^{\prime} \mathrm{W}$ \\
\hline Water depth (m): & 2481.4 \\
\hline Date started $\left(\right.$ UTC $\left.^{*}\right)$ : & 2100 h 20 March 2012 \\
\hline Date finished $\left(\right.$ UTC $\left.^{*}\right)$ : & 2245 h 23 March 2012 \\
\hline Time on hole (days): & 3.1 \\
\hline Seafloor depth DRF $(m)$ : & 2492.9 \\
\hline Penetration DSF (m): & 253.5 \\
\hline Cored interval $(\mathrm{m})$ : & 248.7 \\
\hline Recovered length (m): & 131.46 \\
\hline Recovery (\%): & 53 \\
\hline Drilled interval $(\mathrm{m})$ : & 4.8 \\
\hline Drilled interval (no.): & 1 \\
\hline Total cores (no.): & 32 \\
\hline
\end{tabular}

\begin{tabular}{|c|c|c|c|c|c|c|c|c|c|}
\hline Core & $\begin{array}{l}\text { Top depth } \\
\text { drilled } \\
\text { DSF }(m)\end{array}$ & $\begin{array}{c}\text { Bottom depth } \\
\text { drilled } \\
\text { DSF (m) }\end{array}$ & $\begin{array}{l}\text { Advanced } \\
\text { (m) }\end{array}$ & $\begin{array}{l}\text { Recovered } \\
\text { length } \\
(\mathrm{m})\end{array}$ & $\begin{array}{l}\text { Curated } \\
\text { length } \\
(\mathrm{m})\end{array}$ & $\begin{array}{l}\text { Top depth } \\
\text { cored } \\
\text { CSF }(m)\end{array}$ & $\begin{array}{l}\text { Bottom depth } \\
\text { recovered } \\
\text { CSF }(m)\end{array}$ & $\begin{array}{l}\text { Recovery } \\
\text { (\%) }\end{array}$ & $\begin{array}{l}\text { Time on deck } \\
\text { (UTC*) }\end{array}$ \\
\hline \multicolumn{10}{|c|}{ 340-U1397A- } \\
\hline $1 \mathrm{H}$ & 0.0 & 0.3 & 0.3 & 0.37 & 0.37 & 0.0 & 0.37 & 123 & $3 / 19 / 1209: 25$ \\
\hline $2 \mathrm{H}$ & 0.3 & 9.8 & 9.5 & 9.09 & 9.09 & 0.3 & 9.39 & 96 & $3 / 19 / 1210: 40$ \\
\hline $3 \mathrm{H}$ & 9.8 & 19.3 & 9.5 & 9.92 & 9.92 & 9.8 & 19.72 & 104 & $3 / 19 / 1212: 15$ \\
\hline $4 \mathrm{H}$ & 19.3 & 28.8 & 9.5 & 9.76 & 9.76 & 19.3 & 29.06 & 103 & $3 / 19 / 1213: 00$ \\
\hline $5 \mathrm{H}$ & 28.8 & 36.5 & 7.7 & 7.78 & 7.78 & 28.8 & 36.58 & 101 & $3 / 19 / 1214: 00$ \\
\hline $6 \mathrm{H}$ & 36.5 & 46.0 & 9.5 & 9.63 & 9.63 & 36.5 & 46.13 & 101 & $3 / 19 / 12$ 15:05 \\
\hline $7 \mathrm{H}$ & 46.0 & 55.0 & 9.0 & 9.02 & 9.02 & 46.0 & 55.02 & 100 & $3 / 19 / 12$ 16:05 \\
\hline $8 \mathrm{H}$ & 55.0 & 61.6 & 6.6 & 6.66 & 6.66 & 55.0 & 61.66 & 101 & $3 / 19 / 1218: 25$ \\
\hline $9 \mathrm{H}$ & 61.6 & 66.6 & 5.0 & 5.03 & 5.03 & 61.6 & 66.63 & 101 & $3 / 19 / 12$ 19:10 \\
\hline $10 \mathrm{H}$ & 66.6 & 73.5 & 6.9 & 6.92 & 6.92 & 66.6 & 73.52 & 100 & $3 / 19 / 12$ 20:05 \\
\hline $11 \mathrm{H}$ & 73.5 & 80.5 & 7.0 & 7.01 & 7.01 & 73.5 & 80.51 & 100 & $3 / 19 / 12$ 20:55 \\
\hline $12 \mathrm{H}$ & 80.5 & 87.1 & 6.6 & 6.61 & 6.61 & 80.5 & 87.11 & 100 & $3 / 19 / 12$ 21:45 \\
\hline $13 \mathrm{H}$ & 87.1 & 95.0 & 7.9 & 7.90 & 7.90 & 87.1 & 95.00 & 100 & $3 / 19 / 1222: 30$ \\
\hline $14 \mathrm{H}$ & 95.0 & 101.9 & 6.9 & 6.95 & 6.95 & 95.0 & 101.95 & 101 & $3 / 19 / 1223: 15$ \\
\hline $15 \mathrm{H}$ & 101.9 & 102.1 & 0.2 & 0.16 & 0.16 & 101.9 & 102.06 & 80 & $3 / 20 / 1200: 10$ \\
\hline 161 & \multicolumn{8}{|c|}{$\star \star \star \star \star \star$ Drilled from 102.1 to $106.5 \mathrm{mbsf} \mathrm{f}^{\star \star \star \star *}$} & $3 / 20 / 1200: 25$ \\
\hline $17 \mathrm{H}$ & 106.5 & 110.0 & 3.5 & 3.49 & 3.49 & 106.5 & 109.99 & 100 & $3 / 20 / 1200: 55$ \\
\hline $18 \mathrm{H}$ & 110.0 & 116.3 & 6.3 & 6.30 & 6.30 & 110.0 & 116.30 & 100 & $3 / 20 / 1201: 45$ \\
\hline $19 \mathrm{H}$ & 116.3 & 121.5 & 5.2 & 5.25 & 5.25 & 116.3 & 121.55 & 101 & $3 / 20 / 1202: 45$ \\
\hline $20 \mathrm{H}$ & 121.5 & 121.7 & 0.2 & 0.25 & 0.25 & 121.5 & 121.75 & 125 & $3 / 20 / 1203: 45$ \\
\hline $21 x$ & 121.7 & 131.3 & 9.6 & 0.06 & 0.06 & 121.7 & 121.76 & 1 & $3 / 20 / 1205: 25$ \\
\hline $22 X$ & 131.3 & 140.8 & 9.5 & 0.00 & 0.00 & 131.3 & 131.30 & 0 & $3 / 20 / 1206: 25$ \\
\hline $23 x$ & 140.8 & 150.4 & 9.6 & 0.00 & 0.00 & 140.8 & 140.80 & 0 & $3 / 20 / 1207: 40$ \\
\hline $24 X$ & 150.4 & 160.0 & 9.6 & 1.95 & 1.95 & 150.4 & 152.35 & 20 & $3 / 20 / 1208: 50$ \\
\hline $25 X$ & 160.0 & 169.6 & 9.6 & 8.30 & 8.30 & 160.0 & 168.30 & 86 & $3 / 20 / 1210: 10$ \\
\hline $26 x$ & 169.6 & 179.1 & 9.5 & 4.85 & 4.85 & 169.6 & 174.45 & 51 & $3 / 20 / 1211: 30$ \\
\hline $27 X$ & 179.1 & 188.7 & 9.6 & 1.20 & 1.20 & 179.1 & 180.30 & 13 & $3 / 20 / 1213: 25$ \\
\hline $28 x$ & 188.7 & 198.3 & 9.6 & 1.02 & 1.02 & 188.7 & 189.72 & 11 & $3 / 20 / 1214: 40$ \\
\hline $29 x$ & 198.3 & 207.9 & 9.6 & 0.14 & 0.14 & 198.3 & 198.44 & 1 & $3 / 20 / 1215: 50$ \\
\hline $30 x$ & 207.9 & 217.5 & 9.6 & 0.54 & 0.54 & 207.9 & 208.44 & 6 & $3 / 20 / 1217: 10$ \\
\hline $31 x$ & 217.5 & 227.1 & 9.6 & 0.12 & 0.12 & 217.5 & 217.62 & 1 & $3 / 20 / 1219: 20$ \\
\hline $32 x$ & 227.1 & 236.7 & 9.6 & 0.63 & 0.68 & 227.1 & 227.78 & 7 & $3 / 20 / 1221: 10$ \\
\hline $33 x$ & 236.7 & 246.3 & 9.6 & 0.67 & 0.67 & 236.7 & 237.37 & 7 & $3 / 20 / 1223: 30$ \\
\hline $34 X$ & 246.3 & 255.9 & 9.6 & 2.88 & 2.88 & 246.3 & 249.18 & 30 & $3 / 21 / 1200: 55$ \\
\hline $35 x$ & 255.9 & 265.5 & 9.6 & 3.74 & 3.74 & 255.9 & 259.64 & 39 & $3 / 21 / 1202: 35$ \\
\hline
\end{tabular}


Table T1 (continued).

\begin{tabular}{|c|c|c|c|c|c|c|c|c|c|}
\hline Core & $\begin{array}{l}\text { Top depth } \\
\text { drilled } \\
\text { DSF }(m)\end{array}$ & $\begin{array}{l}\text { Bottom depth } \\
\text { drilled } \\
\text { DSF (m) }\end{array}$ & $\begin{array}{l}\text { Advanced } \\
\text { (m) }\end{array}$ & $\begin{array}{l}\text { Recovered } \\
\text { length } \\
(\mathrm{m})\end{array}$ & $\begin{array}{l}\text { Curated } \\
\text { length } \\
\text { (m) }\end{array}$ & $\begin{array}{l}\text { Top depth } \\
\text { cored } \\
\text { CSF }(m)\end{array}$ & $\begin{array}{l}\text { Bottom depth } \\
\text { recovered } \\
\text { CSF }(m)\end{array}$ & $\begin{array}{l}\text { Recovery } \\
\text { (\%) }\end{array}$ & $\begin{array}{l}\text { Time on deck } \\
\left(\text { UTC }^{*}\right)\end{array}$ \\
\hline \multicolumn{10}{|c|}{ 340-U1397B- } \\
\hline $1 \mathrm{H}$ & 0.0 & 6.6 & 6.6 & 6.60 & 6.60 & 0.0 & 6.60 & 100 & $3 / 21 / 12$ 07:10 \\
\hline $2 \mathrm{H}$ & 6.6 & 16.1 & 9.5 & 9.72 & 9.72 & 6.6 & 16.32 & 102 & $3 / 21 / 12$ 07:55 \\
\hline $3 \mathrm{H}$ & 16.1 & 25.6 & 9.5 & 9.99 & 9.99 & 16.1 & 26.09 & 105 & $3 / 21 / 1208: 55$ \\
\hline $4 \mathrm{H}$ & 25.6 & 34.1 & 8.5 & 8.58 & 8.58 & 25.6 & 34.18 & 101 & $3 / 21 / 12$ 09:55 \\
\hline $5 \mathrm{H}$ & 34.1 & 43.6 & 9.5 & 9.25 & 9.25 & 34.1 & 43.35 & 97 & $3 / 21 / 1210: 35$ \\
\hline $6 \mathrm{H}$ & 43.6 & 53.1 & 9.5 & 9.50 & 9.50 & 43.6 & 53.10 & 100 & $3 / 21 / 1211: 15$ \\
\hline 7H & 53.1 & 61.3 & 8.2 & 8.28 & 8.28 & 53.1 & 61.38 & 101 & $3 / 21 / 1212: 10$ \\
\hline $8 \mathrm{H}$ & 61.3 & 69.6 & 8.3 & 8.37 & 8.37 & 61.3 & 69.67 & 101 & $3 / 21 / 1213: 20$ \\
\hline $9 \mathrm{H}$ & 69.6 & 79.1 & 9.5 & 9.29 & 9.29 & 69.6 & 78.89 & 98 & $3 / 21 / 1214: 10$ \\
\hline $10 \mathrm{H}$ & 79.1 & 87.9 & 8.8 & 8.84 & 8.84 & 79.1 & 87.94 & 100 & $3 / 21 / 1214: 50$ \\
\hline $11 \mathrm{H}$ & 87.9 & 91.7 & 3.8 & 3.86 & 3.86 & 87.9 & 91.76 & 102 & $3 / 21 / 1215: 40$ \\
\hline $12 \mathrm{H}$ & 91.7 & 99.3 & 7.6 & 6.48 & 6.48 & 91.7 & 98.18 & 85 & $3 / 21 / 1216: 30$ \\
\hline $13 \mathrm{H}$ & 99.3 & 103.3 & 4.0 & 4.08 & 4.08 & 99.3 & 103.38 & 102 & $3 / 21 / 1217: 20$ \\
\hline $14 \mathrm{H}$ & 103.3 & 103.5 & 0.2 & 0.20 & 0.20 & 103.3 & 103.50 & 100 & $3 / 21 / 1218: 10$ \\
\hline 151 & \multicolumn{8}{|c|}{$* \star * * *$ Drilled from 103.5 to $108.3 \mathrm{mbsf}{ }^{* \star * * *}$} & $3 / 21 / 1218: 35$ \\
\hline $16 \mathrm{H}$ & 108.3 & 113.0 & 4.7 & 4.77 & 4.77 & 108.3 & 113.07 & 101 & $3 / 21 / 1219: 35$ \\
\hline $17 \mathrm{H}$ & 113.0 & 113.2 & 0.2 & 0.26 & 0.26 & 113.0 & 113.26 & 130 & $3 / 21 / 1220: 30$ \\
\hline $18 \mathrm{X}$ & 113.2 & 122.8 & 9.6 & 0.23 & 0.23 & 113.2 & 113.43 & 2 & $3 / 21 / 1222: 00$ \\
\hline $19 x$ & 122.8 & 132.4 & 9.6 & 0.00 & 0.00 & 122.8 & 122.80 & 0 & $3 / 22 / 1223: 25$ \\
\hline $20 x$ & 132.4 & 141.9 & 9.5 & 0.14 & 0.14 & 132.4 & 132.54 & 1 & $3 / 22 / 1200: 40$ \\
\hline $21 x$ & 141.9 & 151.5 & 9.6 & 0.17 & 0.17 & 141.9 & 142.07 & 2 & $3 / 22 / 12$ 02:05 \\
\hline $22 x$ & 151.5 & 161.1 & 9.6 & 1.80 & 1.80 & 151.5 & 153.30 & 19 & $3 / 22 / 1203: 25$ \\
\hline $23 x$ & 161.1 & 170.7 & 9.6 & 9.76 & 9.76 & 161.1 & 170.86 & 102 & $3 / 22 / 1204: 40$ \\
\hline $24 X$ & 170.7 & 180.2 & 9.5 & 4.98 & 4.98 & 170.7 & 175.68 & 52 & $3 / 22 / 1206: 10$ \\
\hline $25 x$ & 180.2 & 189.7 & 9.5 & 3.08 & 3.08 & 180.2 & 183.28 & 32 & $3 / 22 / 12$ 07:40 \\
\hline $26 x$ & 189.7 & 199.3 & 9.6 & 0.52 & 0.52 & 189.7 & 190.22 & 5 & $3 / 22 / 1209: 05$ \\
\hline $27 X$ & 199.3 & 208.9 & 9.6 & 0.20 & 0.20 & 199.3 & 199.50 & 2 & $3 / 22 / 1210: 30$ \\
\hline $28 x$ & 208.9 & 218.5 & 9.6 & 0.09 & 0.09 & 208.9 & 208.99 & 1 & $3 / 22 / 1212: 10$ \\
\hline $29 x$ & 218.5 & 228.1 & 9.6 & 0.18 & 0.18 & 218.5 & 218.68 & 2 & $3 / 22 / 1214: 30$ \\
\hline $30 x$ & 228.1 & 233.1 & 5.0 & 0.60 & 0.65 & 228.1 & 228.75 & 12 & $3 / 22 / 1219: 05$ \\
\hline $31 x$ & 233.1 & 237.7 & 4.6 & 0.23 & 0.23 & 233.1 & 233.33 & 5 & $3 / 22 / 1222: 05$ \\
\hline $32 x$ & 237.7 & 247.3 & 9.6 & 1.18 & 1.18 & 237.7 & 238.88 & 12 & $3 / 23 / 1202: 00$ \\
\hline \multirow[t]{2}{*}{$33 X$} & 247.3 & 253.5 & 6.2 & 0.23 & 0.23 & 247.3 & 247.53 & 4 & $3 / 23 / 12$ 05:55 \\
\hline & & Totals: & 519.0 & 275.66 & 75.76 & & & & \\
\hline
\end{tabular}

* = ship local time was Universal Time Coordinated (UTC) $-4 \mathrm{~h} . \mathrm{DRF}=$ drilling depth below rig floor, DSF = drilling depth below seafloor, CSF $=$ core depth below seafloor. $\mathrm{H}=$ advanced piston corer, $\mathrm{X}=$ extended core barrel. 
Table T2. Solid-phase geochemistry, Site U1397.

\begin{tabular}{|c|c|c|c|c|c|c|c|}
\hline \multirow{2}{*}{$\begin{array}{c}\text { Core, } \\
\text { section }\end{array}$} & \multicolumn{2}{|c|}{ Depth (mbsf) } & \multicolumn{4}{|c|}{ Carbon (wt\%) } & \multirow{2}{*}{$\begin{array}{c}\text { Nitrogen* } \\
\text { (wt\%) }\end{array}$} \\
\hline & Top & Bottom & $\mathrm{CaCO}_{3}$ & Inorganic & Total $^{*}$ & Organic* & \\
\hline \multicolumn{8}{|c|}{ 340-U1397A- } \\
\hline $2 \mathrm{H}-3$ & 4.05 & 4.06 & 16.14 & 1.94 & & & \\
\hline $2 \mathrm{H}-6$ & 8.46 & 8.47 & 22.71 & 2.72 & & & \\
\hline $3 \mathrm{H}-4$ & 15.02 & 15.03 & 22.68 & 2.72 & & & \\
\hline $4 \mathrm{H}-2$ & 21.97 & 21.98 & 11.56 & 1.39 & & & \\
\hline $4 \mathrm{H}-7$ & 28.56 & 28.57 & 1.13 & 0.14 & & & \\
\hline $5 \mathrm{H}-4$ & 34.55 & 34.56 & 19.44 & 2.33 & & & \\
\hline $6 \mathrm{H}-2$ & 39.09 & 39.10 & 22.07 & 2.65 & & & \\
\hline $7 \mathrm{H}-3$ & 50.18 & 50.19 & & & & & \\
\hline $7 \mathrm{H}-7$ & 54.51 & 54.52 & & & & & \\
\hline $8 \mathrm{H}-1$ & 55.07 & 55.08 & 43.77 & 5.25 & & & \\
\hline $8 \mathrm{H}-1$ & 55.81 & 55.82 & 39.43 & 4.73 & & & \\
\hline $8 \mathrm{H}-1$ & 55.81 & 55.82 & & & & & \\
\hline $9 \mathrm{H}-1$ & 62.08 & 62.09 & 57.12 & 6.85 & & & \\
\hline $9 \mathrm{H}-4$ & 66.07 & 66.08 & 43.64 & 5.23 & & & \\
\hline $10 \mathrm{H}-2$ & 68.915 & 68.925 & 19.38 & 2.32 & & & \\
\hline $10 \mathrm{H}-5$ & 73.16 & 73.17 & & & & & \\
\hline $11 \mathrm{H}-2$ & 76.07 & 76.08 & 13.64 & 1.64 & & & \\
\hline $11 \mathrm{H}-3$ & 77.26 & 77.27 & 20.03 & 2.40 & & & \\
\hline $11 \mathrm{H}-3$ & 77.26 & 77.27 & & & & & \\
\hline $11 \mathrm{H}-5$ & 79.52 & 79.53 & & & & & \\
\hline $12 \mathrm{H}-1$ & 81.63 & 81.64 & 31.24 & 3.75 & & & \\
\hline $12 \mathrm{H}-5$ & 86.755 & 86.765 & & & & & \\
\hline $13 \mathrm{H}-2$ & 89.11 & 89.12 & 0.40 & & & & \\
\hline $13 \mathrm{H}-4$ & 91.27 & 91.28 & & & & & \\
\hline $14 \mathrm{H}-2$ & 95.88 & 95.89 & & & & & \\
\hline $17 \mathrm{H}-2$ & 107.66 & 107.67 & & & & & \\
\hline $18 \mathrm{H}-4$ & 113.98 & 113.99 & & & & & \\
\hline $19 \mathrm{H}-1$ & 116.66 & 116.67 & 29.58 & 3.55 & & & \\
\hline $19 \mathrm{H}-4$ & 121.00 & 121.01 & & & & & \\
\hline $24 X-1$ & 151.21 & 151.22 & 19.30 & 2.31 & & & \\
\hline $25 X-3$ & 163.96 & 163.97 & & & & & \\
\hline $25 X-4$ & 165.61 & 165.62 & 24.17 & 2.90 & & & \\
\hline $26 X-3$ & 173.34 & 173.35 & 34.97 & 4.19 & & & \\
\hline $28 X-1$ & 189.35 & 189.36 & 36.92 & 4.43 & & & \\
\hline $32 X-1$ & 227.61 & 227.62 & 40.34 & 4.84 & & & \\
\hline $32 X-1$ & 227.63 & 227.64 & & & & & \\
\hline $33 X-1$ & 236.85 & 236.86 & 38.78 & 4.65 & & & \\
\hline $34 X-1$ & 246.60 & 246.61 & 27.81 & 3.34 & & & \\
\hline $35 X-2$ & 257.90 & 257.91 & 26.61 & 3.19 & & & \\
\hline \multicolumn{8}{|c|}{ 340-U1397B- } \\
\hline $13 \mathrm{H}-3$ & 102.69 & 102.70 & 2.47 & 0.30 & & & \\
\hline $16 \mathrm{H}-3$ & 111.54 & 111.55 & 11.35 & 1.36 & & & \\
\hline $16 \mathrm{H}-3$ & 112.03 & 112.04 & 1.39 & 0.17 & & & \\
\hline $20 \mathrm{X}-\mathrm{CC}$ & 132.43 & 132.44 & 28.34 & 3.40 & & & \\
\hline $22 X-1$ & 152.35 & 152.36 & 22.51 & 2.70 & & & \\
\hline $32 X-1$ & 238.12 & 238.13 & 31.53 & 3.78 & & & \\
\hline
\end{tabular}

* = total carbon determinations for this site are not reported here. These were often below the inorganic carbon value and would yield negative organic carbon values. These values are available through the database but should be treated with caution. Blank cells = not analyzed. 
Table T3. Composition of interstitial pore water, Site U1397B.

\begin{tabular}{|c|c|c|c|c|c|c|c|c|c|c|c|c|c|c|c|c|c|c|}
\hline \multirow{2}{*}{$\begin{array}{l}\text { Core, } \\
\text { section }\end{array}$} & \multicolumn{2}{|c|}{ Depth (mbsf) } & \multirow{2}{*}{$\begin{array}{l}\text { Alkalinity } \\
(\mathrm{mM})\end{array}$} & \multirow[b]{2}{*}{$\mathrm{pH}$} & \multirow{2}{*}{$\begin{array}{c}\mathrm{Cl} \\
(\mathrm{mM})\end{array}$} & \multirow[b]{2}{*}{ \pm} & \multirow[b]{2}{*}{ Salinity } & \multirow{2}{*}{$\begin{array}{c}\mathrm{NH}_{4} \\
(\mathrm{mM})\end{array}$} & \multirow{2}{*}{$\begin{array}{c}\mathrm{Na} \\
(\mathrm{mM})\end{array}$} & \multirow[b]{2}{*}{ \pm} & \multirow{2}{*}{$\begin{array}{c}\mathrm{Mg} \\
(\mathrm{mM})\end{array}$} & \multirow[b]{2}{*}{ \pm} & \multirow{2}{*}{$\begin{array}{c}\mathrm{K} \\
(\mathrm{mM})\end{array}$} & \multirow[b]{2}{*}{ \pm} & \multirow{2}{*}{$\begin{array}{c}\mathrm{Ca} \\
(\mathrm{mM})\end{array}$} & \multirow[b]{2}{*}{ \pm} & \multirow{2}{*}{$\underset{(\mathrm{mM})}{\Sigma \mathrm{S}}$} & \multirow[b]{2}{*}{ \pm} \\
\hline & Top & Bottom & & & & & & & & & & & & & & & & \\
\hline \multicolumn{19}{|c|}{ 340-U1397B- } \\
\hline $1 \mathrm{H}-3$ & 4.40 & 4.50 & 3.43 & 7.54 & 558.7 & & 36 & 0.09 & 471.3 & 1.7 & 52.9 & 0.3 & 11.0 & 0.1 & 10.2 & 0.1 & 27.7 & 0.3 \\
\hline $2 \mathrm{H}-3$ & 10.82 & 10.92 & & & 557.8 & & & 0.13 & & & & & & & & & & \\
\hline $2 \mathrm{H}-6$ & 15.32 & 15.42 & 4.14 & 8.22 & 560.1 & & 36 & 0.23 & 474.9 & 3.1 & 53.6 & 0.6 & 10.6 & 0.0 & 9.7 & 0.1 & 26.8 & 0.1 \\
\hline $3 \mathrm{H}-2$ & 19.00 & 19.10 & 4.66 & 7.46 & 564.1 & & 37 & 0.25 & 477.4 & 2.9 & 54.0 & 0.4 & 10.6 & 0.1 & 9.4 & 0.1 & 26.6 & 0.2 \\
\hline $3 \mathrm{H}-5$ & 23.36 & 23.46 & 5.08 & 7.58 & 562.2 & & 36 & 0.36 & 473.4 & 2.4 & 53.8 & 0.3 & 10.3 & 0.2 & 9.1 & 0.1 & 26.3 & 0.3 \\
\hline $5 \mathrm{H}-2$ & 37.00 & 37.10 & 5.04 & 7.88 & 570.5 & & 38 & 0.47 & 479.0 & 4.2 & 53.6 & 0.4 & 10.1 & 0.2 & 9.3 & 0.1 & 26.5 & 0.3 \\
\hline $5 \mathrm{H}-6$ & 42.55 & 42.65 & 5.00 & 7.28 & 570.7 & & 37 & 0.48 & 484.6 & 2.7 & 53.4 & 0.3 & 10.4 & 0.2 & 9.2 & 0.1 & 26.4 & 0.3 \\
\hline $6 \mathrm{H}-2$ & 46.50 & 46.60 & 5.11 & 7.51 & 566.2 & 0.7 & 37 & 0.47 & 482.4 & 5.7 & 53.7 & 0.6 & 10.4 & 0.2 & 9.4 & 0.1 & 26.3 & 0.4 \\
\hline $6 \mathrm{H}-6$ & 52.50 & 52.60 & 4.38 & 7.33 & 566.9 & & 37 & 0.45 & 480.8 & 2.4 & 53.3 & 0.3 & 10.6 & 0.1 & 9.2 & 0.1 & 26.2 & 0.2 \\
\hline $9 \mathrm{H}-4$ & 75.55 & 75.65 & 4.06 & 7.60 & 571.2 & & 37 & 0.39 & 482.1 & 4.2 & 53.8 & 0.5 & 10.4 & 0.3 & 9.6 & 0.1 & 27.1 & 0.2 \\
\hline $23 X-2$ & 164.02 & 164.12 & 3.86 & 7.43 & 567.2 & & 38 & 0.25 & 477.0 & 1.5 & 53.5 & 0.4 & 9.8 & 0.3 & 10.8 & 0.1 & 27.3 & 0.4 \\
\hline $23 X-5$ & 168.52 & 168.62 & 4.02 & 8.13 & 568.5 & & 38 & 0.27 & 479.1 & 4.5 & 53.7 & 0.5 & 9.9 & 0.1 & 10.9 & 0.1 & 27.6 & 0.3 \\
\hline $24 X-2$ & 173.60 & 173.70 & 5.00 & 7.94 & 571.2 & & 38 & 0.30 & 496.5 & 9.7 & 55.6 & 1.3 & 10.1 & 0.3 & 11.4 & 0.2 & 28.7 & 0.4 \\
\hline $25 X-1$ & 181.60 & 181.70 & 3.88 & 7.59 & 568.9 & & 38 & 0.32 & 481.9 & 1.8 & 53.7 & 0.3 & 9.9 & 0.2 & 11.0 & 0.0 & 27.7 & 0.1 \\
\hline
\end{tabular}

Uncertainties for $\mathrm{Cl}$ represent $\pm 1 \sigma$ based on repeat analyses. Section 340-U1397B-2H-3 was noted to be particularly sandy during processing and likely had significant contamination during drilling. Shaded samples represent average values for $\mathrm{Na}, \mathrm{Mg}, \mathrm{K}, \mathrm{Ca}$, and $\Sigma \mathrm{S}$ (total sulfur) from duplicate analyses from separate runs.

Table T4. Correlation point picks and depth shifts, Hole U1397B.

\begin{tabular}{rrr}
\hline $\begin{array}{c}\text { Original } \\
\text { depth } \\
\text { (mbsf) }\end{array}$ & $\begin{array}{c}\text { Corrected } \\
\text { depth } \\
\text { (mbsf) }\end{array}$ & $\begin{array}{c}\text { Difference } \\
(\mathrm{m})\end{array}$ \\
\hline 2.193 & 0.771 & 1.422 \\
2.747 & 1.128 & 1.619 \\
3.874 & 2.035 & 1.839 \\
5.656 & 3.689 & 1.967 \\
6.927 & 5.973 & 0.954 \\
7.667 & 6.765 & 0.902 \\
8.457 & 7.591 & 0.866 \\
8.996 & 8.197 & 0.800 \\
9.682 & 8.959 & 0.723 \\
11.723 & 10.403 & 1.320 \\
12.352 & 10.927 & 1.425 \\
13.062 & 11.585 & 1.477 \\
15.602 & 13.930 & 1.672 \\
16.421 & 15.103 & 1.318 \\
16.862 & 15.616 & 1.246 \\
17.212 & 15.950 & 1.262 \\
17.678 & 16.454 & 1.224 \\
19.126 & 18.044 & 1.082 \\
19.669 & 18.271 & 1.398 \\
20.618 & 19.001 & 1.617 \\
21.535 & 19.701 & 1.834 \\
22.428 & 20.555 & 1.872 \\
23.524 & 21.754 & 1.769 \\
24.319 & 22.540 & 1.779 \\
27.671 & 27.859 & -0.188 \\
31.901 & 32.508 & -0.607 \\
36.288 & 35.729 & 0.559 \\
43.878 & 44.162 & -0.284 \\
45.308 & 45.547 & -0.238 \\
48.443 & 48.389 & 0.054 \\
50.909 & 50.820 & 0.089 \\
52.345 & 52.109 & 0.236 \\
52.812 & 52.482 & 0.330 \\
63.988 & 68.480 & -4.492 \\
72.471 & 73.080 & -0.609 \\
\hline & & \\
& & \\
& & \\
16 &
\end{tabular}


Table T5. Samples measured for paleomagnetism, Site U1397.

\begin{tabular}{|c|c|c|}
\hline Core & $\begin{array}{l}\text { Measured } \\
\quad(\mathrm{mT})\end{array}$ & $\begin{array}{c}\text { APC } \\
\text { core barrel }\end{array}$ \\
\hline \multicolumn{3}{|c|}{ 340-U1397A- } \\
\hline $1 \mathrm{H}$ & No, shorter than response function & Nonmagnetic \\
\hline $2 \mathrm{H}$ & $0,10,20$ & Nonmagnetic \\
\hline $3 \mathrm{H}$ & $0,10,20$ & Nonmagnetic \\
\hline $4 \mathrm{H}$ & $0,10,20$ & Nonmagnetic \\
\hline $5 \mathrm{H}$ & 0,20 & Nonmagnetic \\
\hline $6 \mathrm{H}$ & 0,20 & Nonmagnetic \\
\hline $7 \mathrm{H}$ & 0,20 & Nonmagnetic \\
\hline $8 \mathrm{H}$ & 0,20 & Nonmagnetic \\
\hline $9 \mathrm{H}$ & 0,20 & Nonmagnetic \\
\hline $10 \mathrm{H}$ & 0,20 & Nonmagnetic \\
\hline $11 \mathrm{H}$ & 0,20 & Nonmagnetic \\
\hline $12 \mathrm{H}$ & 0,20 & Nonmagnetic \\
\hline $13 \mathrm{H}$ & 0,20 & Nonmagnetic \\
\hline $14 \mathrm{H}$ & 0,20 & Nonmagnetic \\
\hline $15 \mathrm{H}$ & No, core catcher & Nonmagnetic \\
\hline 161 & No, no sample & Nonmagnetic \\
\hline $17 \mathrm{H}$ & 0,20 & Nonmagnetic \\
\hline $18 \mathrm{H}$ & 0,20 & Standard \\
\hline $19 \mathrm{H}$ & 0,20 & Standard \\
\hline $20 \mathrm{H}$ & No, core catcher & Standard \\
\hline $21 x$ & No, core catcher & Standard \\
\hline $22 x$ & No, no sample & Standard \\
\hline $23 x$ & No, no sample & Standard \\
\hline $24 X$ & 0,20 & Standard \\
\hline $25 \mathrm{X}$ & 0,20 & Standard \\
\hline $26 \mathrm{X}$ & 0,20 & Standard \\
\hline $27 x$ & 0,20 & Standard \\
\hline $28 \mathrm{X}$ & 0,20 & Standard \\
\hline $29 x$ & No, core catcher & Standard \\
\hline $30 x$ & 0,20 & Standard \\
\hline $31 x$ & No, core catcher & Standard \\
\hline $32 x$ & 0,20 & Standard \\
\hline $33 x$ & 0,20 & Standard \\
\hline $34 x$ & 0,20 & Standard \\
\hline $35 x$ & 0,20 & Standard \\
\hline
\end{tabular}

\begin{tabular}{|c|c|c|}
\hline Core & $\begin{array}{c}\text { Measured } \\
(\mathrm{mT})\end{array}$ & $\begin{array}{c}\text { APC } \\
\text { core barrel }\end{array}$ \\
\hline \multicolumn{3}{|c|}{ 340-U1397B- } \\
\hline $1 \mathrm{H}$ & 0,20 & Nonmagnetic \\
\hline $2 \mathrm{H}$ & 0,20 & Nonmagnetic \\
\hline $3 \mathrm{H}$ & 0,20 & Nonmagnetic \\
\hline $4 \mathrm{H}$ & 0,20 & Nonmagnetic \\
\hline $5 \mathrm{H}$ & 0,20 & Nonmagnetic \\
\hline $6 \mathrm{H}$ & 0,20 & Nonmagnetic \\
\hline $7 \mathrm{H}$ & 0,20 & Nonmagnetic \\
\hline $8 \mathrm{H}$ & 0,20 & Nonmagnetic \\
\hline $9 \mathrm{H}$ & 0,20 & Nonmagnetic \\
\hline $10 \mathrm{H}$ & 0,20 & Nonmagnetic \\
\hline $11 \mathrm{H}$ & 0,20 & Nonmagnetic \\
\hline $12 \mathrm{H}$ & 0,20 & Nonmagnetic \\
\hline $13 \mathrm{H}$ & 0,20 & Nonmagnetic \\
\hline $14 \mathrm{H}$ & No, core catcher & Nonmagnetic \\
\hline 151 & No, no sample & Nonmagnetic \\
\hline $16 \mathrm{H}$ & 0,20 & Nonmagnetic \\
\hline $17 \mathrm{H}$ & No, clasts & Nonmagnetic \\
\hline $18 \mathrm{X}$ & No, core catcher & Standard \\
\hline $19 X$ & No, no sample & Standard \\
\hline $20 x$ & No, core catcher & Standard \\
\hline $21 x$ & No, core catcher & Standard \\
\hline $22 x$ & 0,20 & Standard \\
\hline $23 x$ & 0,20 & Standard \\
\hline $24 X$ & 0,20 & Standard \\
\hline $25 X$ & 0,20 & Standard \\
\hline $26 \mathrm{X}$ & No, core catcher & Standard \\
\hline $27 x$ & No, core catcher & Standard \\
\hline $28 \mathrm{X}$ & No, core catcher & Standard \\
\hline $29 X$ & No, core catcher & Standard \\
\hline $30 x$ & No, core catcher & Standard \\
\hline $31 x$ & No, core catcher & Standard \\
\hline $32 x$ & 0,20 & Standard \\
\hline $33 x$ & No, core catcher & Standard \\
\hline
\end{tabular}

$\mathrm{APC}=$ advanced piston corer 